KURUMSAL PROJE YÖNETIMI OLGUNLUK

MODELII VE İSTANBUL YEREL YÖNETIMLER UYGULAMASI

\author{
Hacettepe Üniversitesi \\ iktisadi ve idari Bilimler \\ Fakültesi Dergisi \\ Cilt 37, Sayı 3, 2019 \\ s. $391-422$
}

\author{
Canser BİLİR \\ Dr.Öğr. Üyesi, İstanbul Sabahattin Zaim \\ Üniversitesi \\ Mühendislik ve Doğa Bilimleri Fakültesi \\ Endüstri Mühendisliği Bölümü \\ canser.bilir@izu.edu.tr

\section{Yasin İNCE} \\ Yüksek Lisans Öğr., İstanbul Sabahattin \\ Zaim Üniversitesi \\ Fen Bilimleri Enstitüsü \\ yasinince@fatih.bel.tr
}

Bu çalışma, Yasin ince'nin, Dr. Canser Bilir danışmanlığı'nda gerçekleştirdiği “Kurumsal Proje Yönetimi Olgunluk Modeli ve Yerel Yönetimler Uygulaması" isimli Yüksek Lisans tez çalışmasından türetilmiştir.

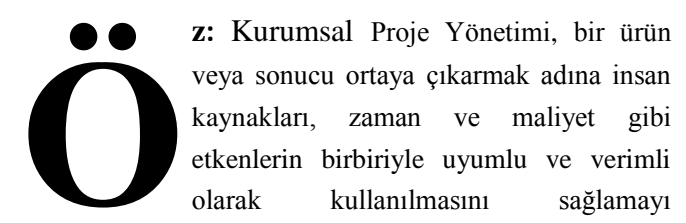

hedeflemektedir. Sınırlı kaynaklarla üst düzeyde hizmet vermeye çalışan yerel yönetimler Kurumsal Proje Yönetimi kavramının önemini gün geçtikçe daha iyi kavramaya başlamışlardır. Bu çalışmada da, Türkiye'deki yerel yönetimlerin, Kurumsal Proje Yönetimi Olgunluk Modellerinden faydalanılarak mevcut olgunluk seviyeleri ve geliş̧me alanları tespit edilmişsir. Çalışmada elde edilen sonuçlar göstermiştir ki, yerel yönetimler proje kapsam yönetimi ve tedarik yönetimi bilgi alanlarında kamu ihale kanununa uygunluk esas alındığı için diğer bilgi alanlarına göre daha yüksek olgunluk seviyesine sahiptir. Yerel yönetimler, takip eden maliyet, zaman, kalite ve iletişim yönetimi alanlarında, ikinci seviye olgunluğa sahiptirler. Diğer yandan, risk yönetimi ve insan kaynakları yönetimi bilgi alanlarında, incelemeye konu olan yerel yönetimler henüz birinci olgunluk seviyesinde yer almaktadırlar. Elde edilen önemli bir sonuç, yerel yönetimlerin Kurumsal Proje Yönetimi olgunluk seviyelerinin birbirleri arasında çok fazla değişmediğidir. Burada, büyükşehir belediyesi olgunluk seviyesi, ilçe belediyeleri olgunluk seviyelerinden olumlu olarak ayrışmaktadır. Yine bazı yerel yönetimler, bazı bilgi alanlarına kısmen daha yüksek notlar elde etmişlerdir. Burada da temel sebep, bu ilçe yönetimlerinde stratejik planlama ve kalite güvence fonksiyonlarının daha olgun bir şekilde gerçekleştiriliyor olmasıdır.

Anahtar Sözcükler: Proje yönetimi, proje yönetimi olgunluk modeli, proje performansl. yerel yönetimler. 



\section{ENTERPRISE PROJECT}

\begin{tabular}{|c|c|}
\hline MANAGEMENT MATURITY & $\begin{array}{l}\text { Hacettepe University } \\
\text { Journal of Economics }\end{array}$ \\
\hline MODEL AND APPLICATION & $\begin{array}{l}\text { and Administrative } \\
\text { Sciences }\end{array}$ \\
\hline TO MUNICIPALITY & $\begin{array}{l}\text { Vol. } 37 \text {, Issue 3, } 2019 \\
\text { pp. 391-422 }\end{array}$ \\
\hline
\end{tabular}

\section{ADMINISTRATIONS IN ISTANBUL}

\author{
Canser BÍLÍR \\ Assist.Prof.Dr., İstanbul Sabahattin Zaim \\ University \\ Faculty of Engineering and Natural Sciences \\ Department of Industrial Engineering \\ canser.bilir@izu.edu.tr
}

\section{Yasin İNCE}

Graduate Student, İstanbul Sabahattin Zaim University

Institute of Science and Technology yasinince@fatih.bel.tr

This paper is adapted from the thesis study, conducted by Yasin ince under the supervision of Dr. Canser Bilir, titled as "Enterprise Project Management Maturity Model and Application to Municipality Administrations".
4

bstract: Project Management aims to ensure that factors such as human resources, time and costs are used in a harmonious and productive manner to bring out a product or a result. Municipality administrations trying to provide high level services with limited resources have started to better understand the importance of project management. In this respect, Project Management Maturity Models have been applied to municipality administrations to identify where they stand in terms of maturity levels and how they need to improve themselves. The results show that municipality administrations have higher level of maturity in scope and procurement management than other knowledge areas as those operations are carried out in compliance with public procurement law. The following cost, time, quality and communication management are in the second maturity level. However, risk management and human resources management are in the first maturity level. One of the important results is that maturity levels of municipality administrations do not vary much among each other. In this sense, the results of metropolitan municipality administration are higher than the results of district municipality centers. In addition, some of local municipalities have achieved higher scores than others due to more matured administration of strategic planning and quality assurance functions.

Keywords: Project management, project managemen maturity model, project performance, municipality administrations. 


\section{GíRIŞ}

Proje yönetimi (PY), belirli bir projenin hedef ve amaçlarına ulaşarak bitirilmesi amaciyla proje kapsam, kaynak ve maliyetlerinin planlanması, zaman, risk, insan kaynakları ve iletişim yönlerinden organize edilmesi ve kaynakların tedarik edilmesi ve tüm bu açılardan yönetilmesi sürecidir (PMI, 2013a). Proje yönetimi, bir ürün ortaya çıkarmak adına insan kaynakları, zaman ve maliyet gibi etkenlerin birbiriyle uyumlu ve aynı zamanda verimli olarak kullanılmasını sağlamaktadır.

Özellikle ellerindeki sınırlı kaynaklarla üst düzeyde hizmet vermeye çalışan yerel yönetimler, PY kavramının önemini gün geçtikçe daha iyi kavramaya başlamışlardır. Bu doğrultuda Proje Yönetim Enstitüsü (PMI) gibi kaynaklarca tanımlanmış olan PY Olgunluk Modellerinden faydalanmaları yerel yönetimlerin projelerde hedefledikleri başarıya ulaşmalarını sağlayacaktır.

PY olgunluk modellerinin arkasında yatan temel düşünce, proje yönetiminde yetkinlik ve mükemmelleşmenin belirli bir olgunlaşma süreci gerektiriyor olduğu gerçeğidir (Kerzner, 2005). Bununla birlikte, PY olgunluk modellerinin, organizasyonların eksik yanlarının tespit edilmesi ile PY kültürünün geliştirilmesinde izlenecek yolun belirlenmesinde önemli bir rolü vardır. PY olgunluk modeli çalışmalarına katılan firmaların büyük bir bölümü, bu çalışmalar neticesinde organizasyonun PY yetkinliklerinde ciddi seviyede artış gözlemlendiğini belirtmişlerdir (Pricewaterhouse, Coopers, 2012).

Kurumsal proje yönetimi, yerel yönetimlerin genel başarısı açısından da vazgeçilmez bir alt sistemdir. Herhangi bir yerel yönetimin bir projedeki başarısı onu temel hedefi olan toplum yararına faaliyette bulunmaya götüreceği için oldukça önemlidir. Ayrıca proje yönetimi, yönetimlerin stratejilerini uygulamaları açısından başvurdukları önemli bir disiplindir. Dolayısıyla belediyelerimizin hedefledikleri dönüşümü gerçekleştirebilme, faaliyetleri tamamlama ve hizmet oluşturma sürecinde başvurmaları gereken önemli bir disiplindir. Şu da göz önünde bulundurulmalıdır ki, projelerin başarı oranını artıran en önemli husus, bütün olarak PY süreçlerinin uygulanması, yani belirli bir olgunluk seviyesine ulaşılmış olmasıdır. Dolayısıyla araştırmada, yerel yönetimlerdeki PY olgunluk seviyesi açısından eksiklikler belirlenerek bunların kurumsal PY olgunluk modeli bağlamında nasıl giderilebileceğinin belirlenmesi, araştırmanın yerel yönetimler için önemini ortaya koymaktadır.

Araştırmanın temel amacı, incelenen yerel yönetimlerin kurumsal PY olgunluk modelinde hangi seviyede olduklarını tespit ederek yönetimin başarısı önündeki engelleri belirlemektir. Mevcut olgunluk seviyeleri ile temel eksikliklerin tespiti 
sonrasında, yerel yönetimler için PY olgunluk seviyelerinin artırılabilmesi için çeşitli önerilerin geliştirilmesi de araştırmanın amaçları arasındadır. $\mathrm{Bu}$ doğrultuda Bütünleşmiş Yönetim Sistemleri Kurumu (IMSI) PY olgunluk seviyesi değerlendirme modeli kullanılarak, yerel yönetimlerimizin PY uygulamaları incelenmiş̧ir.

Araştırma dahilinde, İstanbulda yer alan beş farklı ilçe belediye yönetimi ile büyükşehir belediye yönetiminin PY uygulamaları incelenmiştir. Bu altı farklı yerel yönetimin strateji geliştirme müdürlükleri ve etüt proje müdürlüklerinin görüşlerinden yararlanılmıştır. Dolayısıyla araştırma, İstanbul ilindeki yerel yönetimlerle sınırlıdır. Araştırma kapsamında yer alan yerel yönetimlerimizden verilerin toplanması amacıyla, anket ve yüz yüze görüşme yöntemleri kullanılmıştır. Verilerin toplanması ve değerlendirilmesi sırasında IMSI PY olgunluk değerlendirme modelinden faydalanılmıştır.

Yapılan çalışma sonucunda, çalışma kapsamındaki her bir yerel yönetimlerin, 8 temel PY Bilgi alanı altında 29 alt başılıta notları tespit edilmiştir. Bu notların elde edilebilmesi için önceden belirlenen görüşme formları ve değerlendirme ölçekleri kullanılmıştır. Elde edilen sonuçlar, belediyeleri hem bütün olarak hem de alt başılılar altında birbirleri ile karşılaştırma imkânı vermiş̧ir. Bu notlar ve notların gösterdiği sonuçlar çalışmanın araştırma sonuçları bölümünde detaylı olarak sunulmuştur.

$\mathrm{Bu}$ çalışma beş ana bölüme ayrılmıştır. Çalışmanın bundan sonraki ilk bölümünde PY ve PY olgunluk modelleri kısaca tanttılarak araştırma konusu dahilinde mevcut literatürde yer alan çalışmalar sunulmuştur. Üçüncü bölümde ise çalışmanın amacı, kapsamı ve kullanılan yöntem anlatılmış, dördüncü bölümde ise çalışmada elde edilen sonuçlar ile PY olgunluk seviyesinin artırlabilmesi için çeşitli öneriler sunulmuştur. Sonuç bölümünde ise, elde edilen sonuçlar özet halinde sunularak bundan sonraki çalışmalar için bazı önerilerde bulunulmuş ve çalışma tamamlanmıştır.

\section{LITERATÜR ÖZETI}

Çalışmanın bu bölümünde öncelikle proje ve PY kavramları tanıtılacak, sonrasında ise PY olgunluk modelleri hakkında kısaca bilgi verilecektir. Bu bölümün sonunda ise mevcut literatürde yer alan PY olgunluk modeli çalışmaları kısaca değerlendirilecektir.

\subsection{Proje ve PY Kavramı}

Proje kavramına dair pek çok farklı tanımlama yapmak mümkündür. Geniş anlamda yapılan bir tanımlamaya göre proje, hedef, kaynak gibi kısıtları bulunan, kendine özgü organizasyonel özelliklere sahip olan benzersiz iş ve görevler bütünüdür (Koçel, 2007). Projeler için önemli hedef özgün bir ürün, hizmet veya sonuç 
oluşturmaktır. Cleland ve Ireland (2002)'a göre ise, bir şeyler yaratmak adına daha önceden yapılmamış bir ürün ortaya çıkarmak amacıyla örgütsel kaynakların bir araya getirilmesine proje denir.

Proje Yönetim Enstitüsü’nün yaptığı tanıma göre de, projelerin gereksinimlerini yerine getirmek amaciyla bilgi, beceri, araç ve tekniklerin proje aktivitelerine uygulamasına PY denir. Projelerin yürütülmesinde öncelikli olarak gereksinimlerin belirlenmesi, planlama ve yürütme aşamalarında paydaşların kaygılarının ve beklentilerinin ele alınması, paydaşların arasındaki etkileşimin aktif, etkili ve işbirlikçi bir temele oturtulup bu şekilde korunması ve yürütülmesi ve projenin kısitlarının (kapsam, kalite, zaman çizelgesi, bütçe kaynakları, riskler) dengeli hale getirilmesi gerekmektedir (PMI, 2013b).

\subsection{PY Süreç Grupları}

PMI (2013a)'a göre PY, süreç olarak beşe ayrılır; başlangıç süreçleri grubu, planlama süreçleri grubu, yürütme süreçleri grubu, izleme ve denetim süreçleri grubu ve kapanış süreçleri grubu. Sayılan bu beş süreç grubunun birbirleriyle açık ve net bir bağımlılı̆̆ı vardır. PY tekrara dayalıdır ve bu nedenle süreçler proje yaşam döngüsü boyunca sürekli tekrar edilebilir.

Başlangıç süreçleri grubu, yeni bir proje veya faza başlamak için bu projeyi veya fazı tanımlamak üzere yürütülen süreçlerdir. Bu süreçte bir kapsam belirlenir ve elde edilmesi gereken mali kaynaklar tedarik edilir.

Planlama süreç grubunun ana hedefi, proje amaçlarına ulaşabilmek için gösterilecek çalışmaları belirleyerek gerekli olan eylemler dizisini geliştirmektedir. $\mathrm{Bu}$ süreçte projeyi nihayete ulaştıracak olan proje planları geliştirilir.

Yürütme süreç grubunda yer alan süreçler, PY planında tanımlanan proje şartnamelerini karşılamak amacıyla yürütülen süreçlerdir. Bu süreç grubunun amacı, insanlar ve kaynaklar arasındaki koordinasyonu sağlayarak paydaşların beklentilerinin yönetilmesidir.

İzleme ve denetim süreçleri grubu, projenin performansının izlenerek projede yapılması gereken düzenlemelerin belirlenmesi ve değişikliklerin başlatılması faaliyetlerini içerir.

Kapanış süreçleri grubu ile proje veya üzerinde çalışma yürütülen aşama resmi olarak tamamlanmış olur. 


\subsection{PY Bilgi Alanları}

PMI tarafindan yayınlanan PMBOK kitabı, proje yönetimindeki süreçleri içinde barındıran on farklı bilgi alanı belirlemiştir. Bu bilgi alanlarını sıralamak gerekirse öncelikli olarak proje entegrasyon yönetiminden ve daha sonra da sirasıyla proje kapsam, zaman, maliyet, kalite, insan kaynakları, iletişim, risk, tedarik ve paydaş yönetiminden bahsetmek faydalı olacaktır (PMI, 2013a).

Proje entegrasyon yönetimi bilgi alanı, proje yaşam döngüsü boyunca PY bileşenleri arasındaki koordinasyonu sağlar (Schwalbe, 2002). Proje süreç yönetimi içerisinde birbirinden farklı süreç ve aktiviteler bulunmaktadır. Bu süreç ve aktiviteleri belirlemek ve tanımlamak, ardından da birleştirip koordine etmek için entegrasyon yöntemine başvurulur. Proje entegrasyon yönetimi altı farklı süreçten oluşur. Bunlar; proje başlatma belgesinin geliştirilmesi, PY planının geliştirilmesi, proje çalışmalarının yönlendirilmesi ve yönetilmesi, izlenmesi ve denetimi, bütünleşik değişiklik denetiminin gerçekleştirilmesi ve projenin ya da fazın kapatılması süreçleridir (PMI, 2013a).

Proje kapsam yönetimi, projede yalnızca gerekli çalışmaların yer alması yoluyla projenin başarıya ulaşmasını hedef alan bilgi yönetim sürecidir. Dolayısıyla proje kapsam yönetiminde öncelikli amaç, projeye dahil edilecek ve edilmeyecek çalışmaların belirlenmesidir. PMBOK proje kapsam yönetimini altı ayrı süreçte değerlendirmektedir; kapsam yönetiminin planlanması, gereksinimlerin toplanması, kapsam tanımlanması, İKY oluşturulması, kapsamın onaylanması ve kapsam denetimidir (PMI, 2013a).

Herhangi bir projenin zamanında tamamlanabilmesi adına başvurulacak PY bilgi alanı, proje zaman yönetimidir. Proje zaman yönetimi süreçleri: zaman çizelgesi yönetiminin planlanması, aktivitelerin tanımlanması, aktivitelerin sıralanması, aktivite kaynaklarının tahmin edilmesi, aktivite sürelerinin tahmin edilmesi, zaman çizelgesinin geliştirlmesi ve zaman çizelgesinin denetimi şeklinde sıralanır.

Proje maliyet yönetimi, projenin hedeflediği ürüne ulaşmak maksadıyla maliyetlerin hesaplanması, tahmin edilmesi, bütçelerinin yapılması, finanse edilmesi ve tüm bunların denetimi süreçlerini içerir.

Proje kalite yönetiminde ana amaç, proje nihayetinde ortaya çıkacak olan çıktının, daha önce belirlenmiş olan gereksinimlere sahip olmasını sağlamaktır. Proje kalite yönetiminin üç farklı süreci bulunmaktadır; kalite yönetimi planlaması, kalite güvencesinin sağlanması ve kalitenin denetimi olarak sıralanabilir. 
Proje insan kaynakları yönetimi ise dört farklı süreçten oluşmaktadır. Bunlar; insan kaynakları yönetiminin planlanması, proje ekibinin oluşturulması, proje ekibinin geliştirilmesi ve proje ekibinin yönetilmesi süreçleridir. İnsan kaynaklarının yönetimi dahilinde proje için bir çalışma planı oluşturulur ve PY için personel rolleri ve sorumlulukları belirlenir. Sonrasında proje ekibi oluşturularak, ekibin istenen performans seviyesine ulaşmasını desteklemek amacıyla ekip geliştirme faaliyetleri gerçekleştirilir. Proje süresince, çalışanların performansları denetlenerek varsa sorunlar giderilir ve gerekli durumlarda da ekip değişiklikleri gerçekleştirilir.

Proje iletişim yönetimi, projeye ait bilgilerin doğru zamanda doğru birime (planlama, toplama, üretim, dağıtım vb.) ulaştırılmasını hedef alır. Proje iletişim yönetimi kendi içerisinde üç ayrı sürece ayrılmaktadır. Bunlar sırasıyla iletişim yönetiminin planlanması, iletişimin yönetilmesi ve iletişimin denetimidir.

Proje risk yönetimi bir projede oluşması muhtemel riskleri belirleyip bunları analiz ederek, belirlenen bu risklere yönelik alınacak önlemleri belirleyen bir PY sürecidir. Projenin nihai başarıya ulaşabilmesi adına oluşması muhtemel olumsuzlukları engellemeyi hedefler. Proje risk yönetimi kendi içerisinde altı ayrı sürece ayrılmıştır; risk yönetiminin planlanması, risklerin tanımlanması, niteliksel risk analizinin yapılması, niceliksel risk analizinin yapılması, risk yanıtlarının planlanması ve risklerin denetimidir.

Proje süresince gereksinim duyulan ürün ve hizmetlerin dışarıdan tedarik edilmesi ile ilgili PY bilgi alanı, proje tedarik yönetimi bilgi alanıdır. Tedarik yönetimi, sözleşmeleri veya yetkili proje ekibi üyeleri tarafından çıkarılan satın alma emirlerini hazırlamak ve yönetmek için gerekli sözleşme yönetimi ve değişiklik denetim süreçlerini içerir.

Proje paydaş yönetimi, projeyi etkileyebilecek ya da projenin sonuçlarından etkilenebilecek grupların belirlenmesi ve bunların projeye katılımlarının yönetilmesi ile ilgili bilgi alanıdır. Projelerin başarısı için paydaşların gereksinimlerinin belirlenmesi ve proje süresince yönetilmesi çok önemlidir. Ayrıca çatışmaları yönetmek için paydaşlarla devamlı iletişim halinde kalınması da ayrı bir önem arz etmektedir (PMI, 2013a).

\subsection{PY Olgunluk Modeli}

\subsubsection{PY Olgunluk Modeli Kavramı}

Olgunluk belirli bir beceride istenen seviyeye ulaşmak için, evrimsel bir şekilde ilerlemek olarak tanımlanır (Lahrmann $v d$., 2011). Olgun olmayan organizasyonlarda nihai başarı bireylerin rastgele gösterdikleri performans sonucu ortaya çıkarken, sistematik çalışarak nihai başarıya ulaşmak ancak olgun organizasyonların özelliğidir. 
BILIIR, INCE | Enterprise Project Management Maturity Model and Applications...

Ayrıca, geçmişe ilişkin verileri değerlendirerek, bunları kendi organizasyonları için birer rehber niteliğinde kullanmak olgun organizasyonların özelliklerinden birisidir (Steyn, 2002).

Kurumsal PY olgunluk modeli kavramı ise organizasyonlara, kendi alanlarının en iyi örneklerini ortaya koyarak portföy yönetimi, program yönetimi ve PY ile ilgili genel bir çerçeve oluşturma imkanı sağlamaktadır. Tüm bunların yanında, olgunluk modelleri, portföy, program ve projelerin düzenli olarak başarılı olması için nasıl bir organizasyonel olgunlaşma sürecinin planlanması gerektiğini de tanımlamaktadır (PMI, 2013b). Bir organizasyonun daha yüksek bir olgunluk seviyesine ulaşması ile organizasyon sonuçlarının daha iyi denetlenmesi, maliyet, amaç ve performans tahminlerinde daha isabetli olunması, nihai amaca ulaşmak için etkinlik kapasitelerinin artırılması ve yönetim kabiliyetinin en üst düzeye ulaşması beklenir. (McCormack $v d$., 2009).

PY olgunluk modelleri genel olarak değerlendirildiğinde, olgunluk modellerinde ortak olarak beş ayrı aşama bulunduğu gözlemlenebilir (Şekil 1). Bunlar sırasıyla; başlangıç süreci, tekrarlanabilir süreç, tanımlanmış süreç, yönetilen süreç ve iyileştirme sürecidir.

Şekil 1. PY Olgunluk Seviyeleri

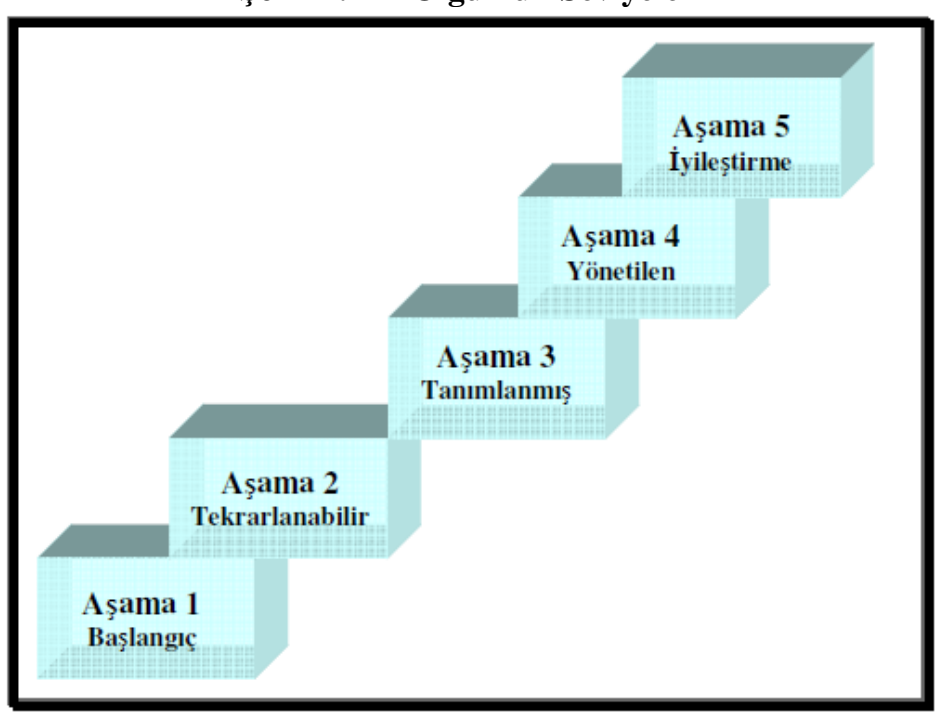

Kaynak: Kerzner (2005). 
PY olgunluk seviyesi henüz başlangıç sürecinde olan organizasyonlarda, organizasyonun ana işlevi net bir biçimde tanımlanmış değildir. Bu süreci geçememiş organizasyonlar, proje başarısının bir PY sistemi ile değil bireylerin kendi çabalarıyla mümkün olacağını düşünürler.

PY olgunluk modellerinin ikinci aşaması olan tekrarlanabilir süreçte maliyet, zaman ve kalite gibi temel PY ölçütlerinin takibi yapılmaktadır. Bu kısımda projeye ait tüm teknik ve idari verilerin tahminleri yapılarak belgelendirilir. Projenin geliştirilmesi sürecinde projenin ana aşamaları ile gerekli aktiviteler belirlenmeli, aktiviteler için gereksinim duyulacak kaynaklar tanımlanmalıdır. Bunun yanında süre tahminleri yapılarak, riskler belirlenmeli ve proje bütçesi oluşturulmalıdır. Ayrıca, projenin sponsoru ve sorumlusu da önceden belirlenmeli, proje ekip üyelerinin isimleri, sorumlulukları ve pozisyonları da belgelendirilmelidir (Steyn, 2002).

PY olgunluk modelinin üçüncü aşaması olan "Olgunluk" aşamasında, artık PY en iyi uygulamaları bir organizasyon kültürü haline getirilmiş ve organizasyon ile bütünleşmiştir. Farklı projeler arasındaki görünen veya görünmeyen maliyetler öngörülmekte ve bu yolla finansal ölçütler kullanarak yatırımın geri dönüşü ya da geri ödeme süresi gibi analizlerle projeler seçilmektedir (Kerzner, 2005). Bu aşamada, projeye ait bilgi akışının proje boyunca izlenmesi nihai başarı için oldukça önemlidir. (PMI, 2013b).

Tanımlanmış olan proje gereksinimlerinin karşılandığı ve proje performanslarının denetim altında tutulabildiği olgunluk seviyesi yönetilen süreç olarak adlandırılmaktadır ve olgunluk modellerinin dördüncü aşamasıdır. Bu aşamada kritik ölçütlerin oluşturulmasının yanı sıra, kalite yönetiminin başarılı bir şekilde gerçekleştirilmesi oldukça önemlidir. Ek olarak, proje ekibinin kültürel gelişiminin sağlanabilmesi için tüm proje ekibinin yani, proje yönetici ve personelinin bu aşamada devamlı bir şekilde yenilikleri takip eder bir niteliğe sahip olmaları gerekir.

PY olgunluk modelinin son aşaması olan iyileştirme süreci, kurumsallaşmanın gerçekleştiği ve geri dönüşlerin düzenli olarak değerlendirmeye alındığı iyileştirme aşamasıdır (Kerzner, 2005). Bu aşamada proje yöneticilerinin ve proje ekibinin, proje için uygulanacak olan aktiviteleri devamlı olarak takip etmeleri esastır. Faaliyetlerin hata ile sonuçlanmasını beklemeden proaktif bir sorun yönetimi yapılmalıdır. Ayrıca gerçekleştirilen değerlendirmeler yardımıyla önceki projelerde ortaya çıkan sorunlarla gelecek projelerde karşılaşılmaması beklenir. 
BILIR, INCE | Enterprise Project Management Maturity Model and Applications...

\subsubsection{PY Olgunluk Modelleri}

Çalışmanın bu bölümünde, en yaygın olarak kullanılan farklı PY Olgunluk Modelleri (PMMM) tanıtılmaktadır. Bu PY olgunluk modelleri şunlardır:

- $\quad$ Proje Yönetimi Enstitüsü tarafindan sunulan Organizasyonel Proje Yönetimi Olgunluk Modeli (OPM3)

- $\quad$ Kerzner Proje Yönetimi Olgunluk Modeli (K-PMMM)

- $\quad$ Proje, Program ve Portföy Yönetimi Olgunluk Modeli (P3M3)

- $\quad$ IMSI Proje Yönetimi Olgunluk Değerlendirme Modeli

\subsubsection{Organizasyonel Proje Yönetimi Olgunluk Modeli (OPM3)}

Organizasyonel PY Olgunluk Modeli 1998 yllında, Proje Yönetimi Enstitüsü tarafından tanımlanmıştır. OPM3 olarak da adlandırılır. 1998'den beri gelişmeye devam eden OPM3, organizasyonel PY olgunluğunun iyileştirilmesi için kullanılan tüm yönergeleri açıklar. Bunun yanı sıra, OPM3, en iyi uygulamalar için organizasyonun proje, program ve portföy yönetimini bir araya getiren bir çerçeve oluşturmaktadır. OPM3'ün değerlendirme anketi 151 soru içerir ve kuruluşun PY olgunluğu hakkında yüksek düzeyde değerlendirme imkanı sunar (PMI, 2013b). OPM3 özellikleri (PMI, 2013b);

- Dünya çapında kabul edilebilir bir ölçüt olan PMBOK'ı temel alır.

- Yayıncısı PMI, PY için dünya genelinde bir kaynak olarak kabul edilmektedir.

- Stratejik yönetimi kapsar.

- Proje, program ve portföy yönetimi konularını kapsamaktadır.

- Öz-değerlendirme ve PY olgunluğunun dış değerlendirmesi için araçlar sağlar.

- Gücü ve zayıflı̆̆ tanımlar ve geliştirmek için alternatifler önerir.

- Geliştirmelere öncelik vermek için yol belirlemeye yardımcı olur.

- Mevcut olgunluk seviyesinin değerlendirilmesi düşük maliyetlidir

- Sektör bağımsızdır. 


\subsubsection{Kerzner Proje Yönetimi Olgunluk Modeli}

Kerzner, 2005 y1lında PMBOK'un bilgi alanlarına dayanarak PY Olgunluk modelini ortaya koymuş ve PY için beş olgunluk seviyesi tanımlamışıtır: Ortak dil, ortak süreçler, tekil metodoloji, kıyaslama, sürekli iyileştirme. Bu olgunluk modeli Kerzner Proje Yönetimi Olgunluk Modeli (K-PMMM) olarak da adlandırllır. K-PMMM özellikleri (Kerzner, 2005):

- PMBOK'a dayanmaktadır.

- Sadece stratejik proje yönetimini kapsar. Program ve portföy yönetimini kapsamaz.

- Olgunluk değerlendirmesi için aşamalı yaklaşımı izler

- Düşük seviyede, mevcut olgunluk seviyesini değerlendirme zorluğuna sahiptir ve değerlendirme maliyeti oldukça düşüktür.

- OPM3'e benzer şekilde, K-PMMM aynı zamanda gücü ve zayıflığı tanımlar ve geliştirilecek alternatifler sunar.

- Anlama ve yürütme için düşük zorluk seviyesine sahiptir.

- Sektörden bağımsızdır.

\subsubsection{Proje, Program ve Portföy Yönetimi Olgunluk Modeli}

Proje, Program ve Portföy Yönetimi Olgunluk Modeli (P3M3) ilk olarak 2006 yılında İngiliz Hükümeti, Hükümet Ticaret Ofisi (OGC) tarafindan sunulmuştur. Olgunluk modeli temelde bir PY yaklaşımı olan Prince2 prensiplerine dayanmaktadır. P3M3 üç farklı alt-olgunluk modeli sunmaktadır. Bu olgunluk modelleri: Portföy Yönetimi (PfM3), Program Yönetimi (PgM3) ve Proje Yönetimi (PjM3)'dir. P3M3, kurumun alt-olgunluk modelinin her biri için yedi temel alana karşı performansını ölçer. Bunlar sırasıyla; örgütsel yönetim, yönetim denetimi, fayda yönetimi, risk yönetimi, paydaş yönetimi, finansal yönetim ve kaynak yönetimidir. P3M3 Özellikleri (OGC, 2015);

- Yayıncıs1 OGC'dir.

- Proje, program ve portföy yönetimini kapsar.

- Olgunluk değerlendirmesi için aşamalı yaklaşımı izler.

- En iyi uygulamaların listesini sunar.

- Mevcut olgunluk seviyesini değerlendirmek göreceli olarak zordur. 

düzeydedir.

- Kolayca uygulanabilir ancak basitliği ve anlaşılma seviyesi orta

- Sektörden bağımsızdır.

\subsubsection{Proje Bütünleşik Yönetim Sistemleri Olgunluk Modeli (IMSI)}

Bütünleşik Yönetim Sistemleri Olgunluk Modeli, Integrated Management Systems Incorporated tarafından yayınlanmıştır. IMSI'nin PY değerlendirme modeli, tipik olarak beş aşamalı bir olgunluk modeli içermektedir. IMSI PY olgunluk modelinin ana amacı, organizasyonların PY süreçlerini, unsurlarını ve sağlayıcılarını daha iyi kullanmasına yardımcı olmaktır. IMSI değerlendirme modeli, PY bilgi alanlarının her birini, bunlarla ilişkili olan kritik unsurları ve süreçleri inceleyerek değerlendirir. PY olgunluk seviyesi değerlendirmesi ile iyileştirilmesi gereken alanlara öncelik verilmesi hedeflenmektedir. Ayrıca kuruluşun hedeflerine yönelik ilerlemeyi izleyebileceği bir temel de oluşturmaktadır. Nihayetinde organizasyonun bir PY mükemmelliği kültürü oluşturmasına yardımcı olmak amaçlanmaktadır. Özellikleri (Holmes, Walsh, 2005):

- Proje yönetimini kapsar.

- Olgunluk değerlendirmesi için aşamalı bir yaklaşım izler. düşüktür.

- Mevcut olgunluk seviyesini değerlendirme zorluğu OPM3'e kıyasla

- Güçlü yönler ile zayıf yönlerin neler olduğunu tanımlar ve geliştirmek için alternatifler önerir.

- Anlama ve yürütme için düşük zorluk derecesine sahiptir.

- Değerlendirme maliyeti düşüktür ve sayısallaştırılması diğer modellere göre daha kolaydır.

\subsection{Literatür Araştırması}

90'lı y1llarda PY kavramının organizasyonel seviyede dikkat çeken bir konu haline gelmesinden sonra birçok PY olgunluk modeli ortaya çıkmış ve bu alanda belirli bir literatürün oluşmuştur (Gorog, 2016). Bu konudaki akademik yayınlar iki ana gruba ayrılmaktadır: olgunluk modelleri ve olgunluk seviyesi değerlendirme sonuçları.

PY olgunluk modeli literatürünün önemli bir kısmını olgunluk modellerinin kendisi ve bu modeller ile ilgili karılaştırmalı çalışmalar oluşturmaktadır. Literatürde yaygın olarak bilinen 30'un üzerinde PY olgunluk modeli mevcuttur (Kwak vd., 2015). 1990'lı yılların sonunda başlayıp 2000'li yıllar boyunca birçok organizasyon (PMI, 2013b; OGC, 2015; Holmes, Walsh, 2005); ve araştırmacı (Crawford, 2007; Kerzner, 2005; Cooke-Davies, 2004), yeni PY olgunluk modelleri geliştirerek sunmuşlardır. Yeni 
olgunluk modellerinin geliştirilmesi süreci hala devam etmektedir. Mevcut olgunluk modellerinin eksikliklerinden hareket ederek veya belirli bir endüstri veya konuda kullanılmak üzere yeni olgunluk modelleri hala geliştirilmektedir. Örneğin, Nikkhou, Taghizadeh ve Hajiyakhchali mevcut olgunluk modellerinin portföy yönetimi üzerinde yeterince durmadığını belirterek ELENA adını verdikleri olgunluk modelini 2016 yllında ortaya atmışlardır (Nikkhou $v d$., 2016). PY olgunluk modeli literatüründe olgunluk modellerini inceleyerek karşılaştıran birçok çalışma da mevcuttur. Gorog 2016 yılında yayınlanan çalışması ile mevcutta yaygın olarak bilinen tüm PY olgunluk modellerini, kapsayıcılık, kullanım kolaylığı gibi farklı boyutlarla değerlendirmiş, yaptı̆̆ı saha çalışması ile derlediği olgunluk modellerine yöneltilen eleştirileri de sunmuştur (Gorog, 2016).

PY olgunluk modelleri ile ilgili literatürün ikinci kısmını çeşitli organizasyonlara uygulanan proje olgunluk modellerinin sonuçları oluşturmaktadır. Bu alandaki literatür görece daha kısıtlı olmakla birlikte, yine de birçok çalışma bulmak mümkündür. Kwak, Sadatsafavi, Walewski ve Williams 2015 yılında yayınladıkları çalışma ile Ortadoğu'da yer alan bir inşaat firmasının PY alanında son 30 yıldaki gelişimini incelemiş ve firmada kullanılan olgunluk modellerinin gelişimine etkisini tespit etmeye çalışmışlardır. Cooke-Davies ve Arzymanow ise 2003 yılında yaptıkları çalışma ile 6 farklı sektörde (Petrokimya, Savunma, Eczacılık, İnşaat, Telekomünikasyon ve Finansal Hizmetler) yer alan 21 firmanın PY olgunluk seviyelerini belirlemişlerdir. 10 farklı başlık altında gerçekleştirilen çalışma ile sektörler ve firmalar arasındaki farklılıklar sebepleri ile birlikte tespit edilmeye çalışılmıştır (Cooke-Davies, Arzymanow, 2003). Backlund, Chroner ve Sundqvist ise PY olgunluk modellerini amaç, güçlü ve zayıf yönler gibi birçok açıdan değerlendirmiş, İsveç’te yer alan proje bazlı yedi firmada gerçekleştirdikleri saha çalışması ile de olgunluk modellerinin uygulanma sürecini ve karşılaşılan zorlukları tespit etmişlerdir (Backlund vd., 2014).

Bu alanda ülkemizde gerçekleştirilen çalışmalar ise oldukça sınırlıdır. Ülkemizde yapılan bir çalışmada Demir ve Kocabaş (2010), PY olgunluk modellerini sunarak eğitim kurumlarını PY olgunluk modelleri açısından değerlendirmişlerdir. Ancak bu çalışmada herhangi sayısal bir değerlendirme sunulmamıştır. 2015 yılında gerçekleştirilen bir yüksek lisans çalışması ile teknoloji geliştirme firmalarının PY olgunluk seviyeleri 8 farklı boyutta değerlendirilmiştir. Ayrıca elde edilen sonuçlar üzerinden mevcut olgunluk seviyelerinin artırılması için öneriler de geliştirilmiştir (Yıldız, 2015). Yine bir başka tez çalı̧̧masında ise Kerzner PY olgunluk modelinden faydalanılarak bir ilaç firmasının olgunluk seviyesi değerlendirilmiş̧iir (Onur, 2007). Bunların dışında kamu kurumlarımızda diğer alanlardaki olgunluk seviyelerini ölçen çalı̧̧malar da mevcuttur. Örneğin, gerçekleştirilen bir çalışma ile Kalkınma Ajanslarının süreç olgunluk seviyeleri ölçülmüş ve performansın geliştirilmesi için öneriler getirilmiştir (Efe, 2018). Ancak bu çalışmada PY olgunluğuna değinilmemiştir. Yerel 
BİLIR, İNCE | Enterprise Project Management Maturity Model and Applications...

yönetimlerde PY ile ilgili olarak gerçekleştirilen bir diğer yüksek lisans tez çalı̧̧masında ise projelerin seçimi konusu ele alınmış, Analitik Hiyerarşi Süreci kullanılarak projelerin seçilmesi önerilmiştir. Bu çalışmada da PY olgunluk seviyesi ile ilgili bir değerlendirme yapılmamıştır (Ünle, 2007).

Bunların dışında ülkemizde kamu kuruluşlarında veya yerel yönetimlerde PY olgunluk seviyesini ölçen herhangi bir çalışma yayınlanmamıştır. Dolayısıyla bu çalışma yerel yönetimlerde PY olgunluk seviyesini ölçen ilk çalışma olarak literatüre katkıda bulunacaktır. Yine ülkemizde kamu kurumlarında PY olgunluk seviyesi ile ilgili ilk çalışma olma özelliğini de taşımaktadır.

\section{ARAŞTIRMA YÖNTEMI}

Çalışmanın bu bölümünde gerçekleştirilen araştırmanın amacı, önemi, kapsamı ve kısıtları ile kullanılan yöntem gibi bilgiler sunulmaktadır.

\subsection{Araştırmanın Amacı}

Araştırmanın amacı, İstanbul ili yerel yönetimlerimizin kurumsal PY olgunluk modelinde hangi seviyede olduklarını, tespit ederek, yönetimin PY alanındaki başarısı önündeki engelleri belirlemektir. Mevcut durumun saptanmasının ardından, yerel yönetimlerimizin PY olgunluk seviyelerinin artırılabilmesi için çeşitli tavsiyelerde bulunmak da araştırmanın ana hedeflerindendir. Bu doğrultuda IMSI PY olgunluk seviyesi değerlendirme modeli kullanılarak, yerel yönetimlerin projeleri nasıl yönettiğinin belirlenmesi ve projede başarı olasıllğı arttırmak için çeşitli önerilerin geliştirilmesi hedeflenmiştir. Dolayısıyla, kurumların PY yaklaşım ve uygulamalarını daha etkili kullanmalarına yardımcı olunacaktır.

\subsection{Araştırmanın Önemi}

Kurumsal PY, yerel yönetimlerin genel başarısı açısından vazgeçilmez bir alt sistemdir. Her hangi bir belediyenin belirli bir projedeki başarısı onun temel hedefi olan toplum yararına faaliyette bulunmasına yardımcı olacağı için oldukça önemlidir. Ayrıca proje yönetimi, tüm organizasyonların stratejilerini uygulamak için başvurdukları önemli bir disiplindir. Dolayısıyla da, belediyelerimizin hedefledikleri dönüşümü gerçekleştirme, faaliyetleri tamamlama ve hizmet oluşturma sürecinde başvurmaları gereken önemli bir disiplindir. Şu da mutlaka göz önünde bulundurulmalıdır ki, projelerin başarı oranını artıran en önemli husus, bütün olarak PY süreçlerinin uygulanması, yani PY açısından belirli bir olgunluk seviyesine ulaşılmış olmasıdır. Dolayısıyla, yerel yönetimlerimizin PY olgunluk seviyesinin artırılabilmesi önündeki eksiklik ve kusurları belirlemeyi ve bunların kurumsal PY olgunluk modeli bağlamında nasıl giderileceğini tespit etmeyi hedefleyen bu çalışma, yerel yönetimlerimizin stratejik hedeflerine ulaşabilmeleri için bir yol gösterici niteliktedir. 


\subsection{Araştırmanın Kapsamı ve Kısıtları}

Araştırma, İstanbul'da bulunan beş farklı ilçe belediyesi ve İstanbul Büyükşehir Belediye yönetiminin PY etkinlikleri değerlendirilerek gerçekleştirilmiştir. Çalışmada, bu altı farklı belediyenin strateji geliştirme müdürlükleri ve etüt proje müdürlüklerinin görüşlerinden yararlanılmıştır. Dolayısıyla araştırma, İstanbul ilindeki yerel yönetimlerin PY yetkinlikleri ile kısıtlıdır. Bu hali ile çalışma tüm Türkiye yerel yönetimlerini temsil etmemekle birlikte, diğer yerel yönetimlerdeki uygulamaları yorumlamak ve anlamak için iyi bir örnek teşkil etmektedir.

Çalışmanın önemli kısıtlarından bir tanesi de, yerel yönetimlerdeki proje ve PY algısının genelde "dış bir tedarikçi firma tarafından gerçekleştirilen işler" olarak anlaşılmasıdır. Dolayısıyla yapılan görüş̧melerde ve alınan sonuçlarda bu anlayış önemli ölçüde etkili olmuştur.

\subsection{Araştırmanın Yöntemi}

Araştırma kapsamındaki yerel yönetimlerimizden verilerin toplanması sırasında anket ve yüz yüze görüşme yöntemleri kullanılmıştır. Görüşme formunun oluşturulması, verilerin toplanması ve değerlendirilmesi sırasında, IMSI PY olgunluk değerlendirme modelinden faydalanılmıştır. IMSI olgunluk modeli temelde iki sebepten dolayı bu araştırmada kullanılmıştır. Bu sebeplerden birincisi, bu her bir PY bilgi alanında anlaşılabilir sorularla birlikte mevcut durumu basit bir şekilde değerlendirme imkanı sunmasıdır. İkinci sebep ise, anket sorularına verilen cevapların sayısallaştırılması ve eksik yönlerin belirlenmesindeki kolaylıktır. Yine bu modelin, mevcut literatürde birçok uygulamasının olması da önemli bir sebeptir.

IMSI'a göre kullanılacak olan görüşme formu, değerlendiricilerin, olgunluk değerlendirmesini tamamlamak için gereksinim duydukları bilgileri derlemek için kullandıkları önemli bir araçtır (Holmes, Walsh, 2005). Kullanılan görüşme formu ile birlikte, incelenen yerel yönetimin PY uygulamalarının hangi olgunluk seviyesinde olduğu belirlenmektedir. Bu değerlendirme, 8 farklı PY bilgi alanı üzerinden yine her bir bilgi alanının alt başlıkları da incelenerek gerçekleştirilmektedir.

\section{ARAȘTIRMANIN BULGULARI}

Çalışmanın bu bölümünde, gerçekleştirilen araştırmanın sonuçları sunulmuştur. İlk olarak tüm yerel yönetimlerimizi kapsayan ve tüm bilgi alanlarını içeren genel bir değerlendirme yapılmış, sonrasında ise sırası ile her bir bilgi alanında elde edilen sonuçlar detaylı olarak sunulmuştur. 


\subsection{PY Genel Değerlendirmesi}

Şekil 2'de görüldüğü gibi, araştırma dahilindeki yerel yönetimlerimiz, kapsam yönetimi ve tedarik yönetimi bilgi alanlarında göreceli olarak daha yüksek olgunluk seviyelerine sahiptirler. Bunun temel sebebi, yerel yönetimlerimizde bu faaliyetlerin, 4734 sayılı kamu ihale kanununa uygunluk esas alınarak gerçekleştiriliyor olmasıdır.

Yerel yönetimlerimizin mevcut uygulamalarının olgunluk seviyesi bunu takip eden maliyet, zaman, kalite ve iletişim yönetimi bilgi alanlarında ise ikinci olgunluk seviyesi civarında seyretmektedir. Bu bilgi alanlarında, ikinci olgunluk seviyesi tespit edilmesinde ana etken, mevzuatın belirlediği ölçütler, tek biçim formlar, kamu birim fiyat kitapları, idari sözleşme tasarıları, iş programları ve teknik şartnamelere uygunluk gibi birçok zorlayıcı uygulamanın bulunmasıyla birlikte, bu uygulamaların bilgi alanlarındaki tüm temel gereklilikleri yerine getirmiyor olmasıdır.

Bir diğer yandan, risk yönetimi ve insan kaynakları yönetimi bilgi alanlarında ise mevcut olgunluk seviyesi diğer bilgi alanlarına kıyasla daha düşük seviyede, yani birinci (başlangıç) seviyede olarak tespit edilmiştir.

Yerel yönetimlerimizde olgunluk seviyeleri çalışmasından elde ettiğimiz önemli bir diğer sonuç ise, bilgi alanları arasında yerel yönetimlerimiz arasında çok büyük farklılıklar olmadığı sonucudur. Örneğin, kapsam yönetimi bilgi alanında tüm yerel yönetimlerimiz daha yüksek olgunluk seviyesine sahipken risk yönetimi bilgi alanında ise daha düşük olgunluk seviyesine sahiptirler. Bunun yanında yine de bazı bilgi alanlarında yerel yönetimlerimiz arasında farklılık olduğu tespit edilmiştir. Yapılan çalışma ile birlikte bu nispi farklılığın, stratejik yönetim yapısı ile profesyonel proje yöneticilerinin var olup olmamasından kaynaklandığı sonucuna ulaşılmıştır. Yine Büyükşehir Belediyesinin olumlu manada ayrışan olgunluk seviyesi, diğer belediyelere göre daha kurumsal projeler yürütebilmesi, proje yönetiminde daha ileri olgunluk seviyesinde bulunması, PMI metodolojisini uygulamaya çalş̧1lıyor olması gibi sebeplerden kaynaklanmaktadır. Büyükşehir Belediyesinin, PY alanında iş kırılım yapısının oluşturulması, planlanan ve gerçekleşen bütçe karşılaştırmalarının periyodik denetimi, genel bir risk yapısının oluşturulması, PY ofislerinin oluşturulması, projelere ait performans raporlarının hazırlanması gibi uygulamalarla önemli oranda ilçe belediyelerinden ayrıştığı da görülmektedir. 


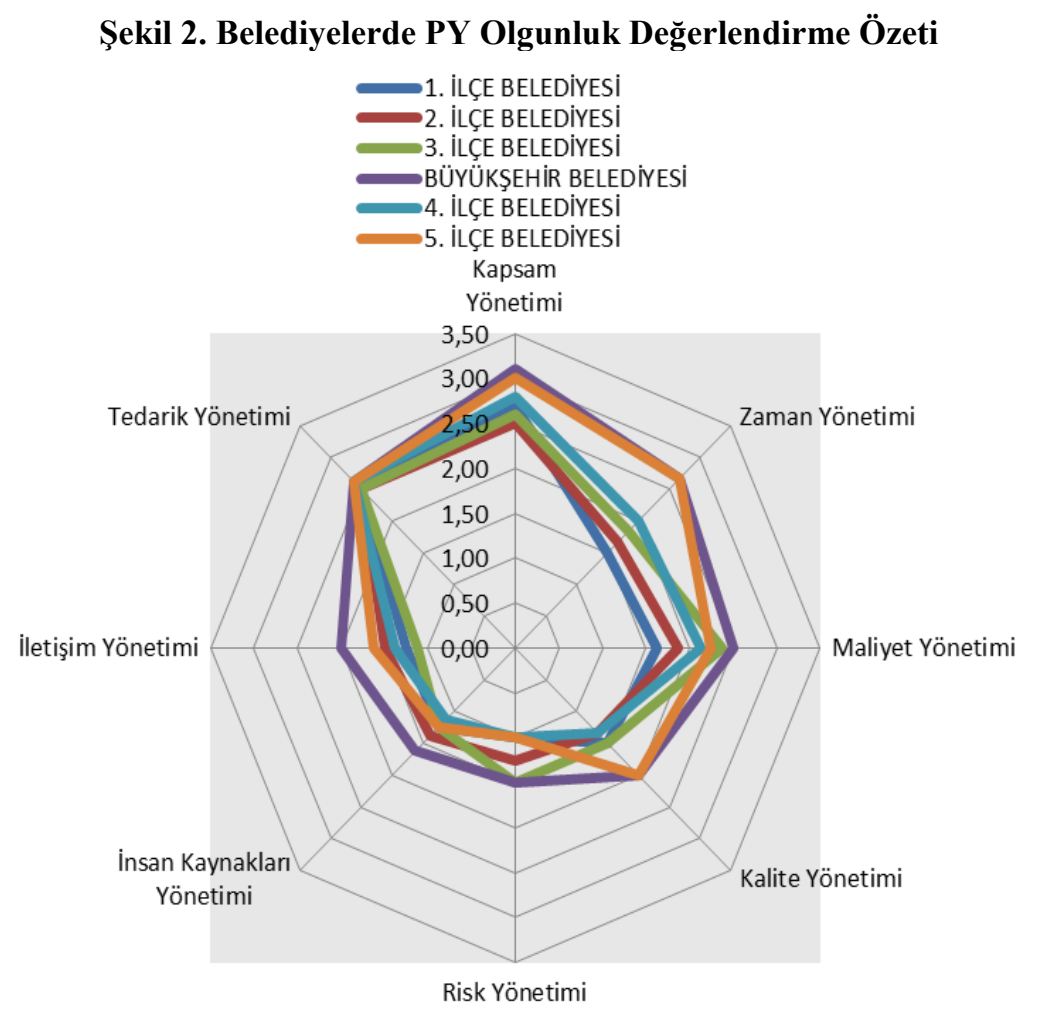

\subsection{Proje Kapsam Yönetimi}

Yerel yönetimlerimizin PY olgunluk seviyelerini belirlemek adına incelediğimiz ilk bilgi alanı, proje kapsam yönetimidir. Kapsam yönetimi bilgi alanında yüksek bir olgunluk seviyesinde olunabilmesi için, proje için sadece gerekli olan tüm işlerin gerçekleştirilmesi ve bunun için gerekli olan çalışma ve denetimlerin düzenli olarak gerçekleştiriliyor olması gereklidir.

Kapsam tanımlama olgunluk seviyesinin belirlenmesi adına yapılan çalışma sonucunda, kapsam tanımlamasının mevzuat çerçevesinde yapıldığı bilgisine ulaşılmıştır. Şartnameler yardımı ile proje kapsam tanımı belirlenmektedir. Bunların yanı sıra şartnameler içerisinde kabul edilen varsayımlar ve kısıtlamalar da belirtilmektedir. Tüm bu veriler doğrultusunda, Şekil 3'de de görüldüğü gibi kapsam tanımı alt grubunun PY olgunluk seviyesi üçüncü seviye olarak belirlenmiş̧tir. 


\section{Şekil 3. Proje Kapsam Yönetimi Olgunluk Değerlendirmesi}

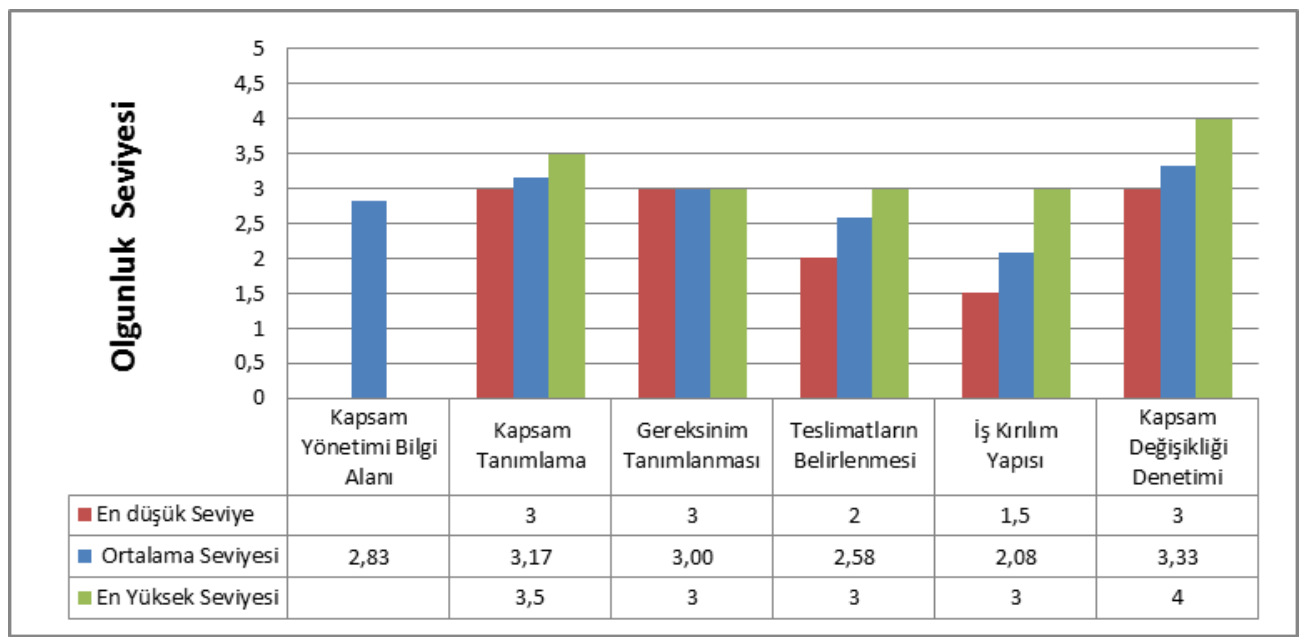

Gerçekleştirilen araştırma ile birlikte, proje gereksinimlerinin genel olarak belirli süreçler işletilerek saptandığı tespit edilmiştir. Ayrıca bu gereksinimlerin takibi sağlanmakta ve ana paydaşlarla da görüş alışverişinde bulunularak belirlenmektedir. Bunlarla birlikte, teknik gerekliliklerin belgelenip ölçüldüğü de söylenebilir. Yine, teknik şartnameler tek biçim formlar kullanılarak toplanmaktadır. Fakat tüm gereksinimlerin proje ekibi tarafindan onaylandığı söylenemez. Ayrıca, gereksinimlerdeki değişiklikler diğer programlara uygunluk açısından değerlendirilmemekte, öğrenilen dersler de belgelendirilmemektedir.

Teslimatların belirlenmesi açısından bakıldığında ise, proje teslimatlarının şartnameler dahilinde gerçekleştiği sonucuna ulaşılmıștır. Bunun yanında, teslimatların belgelendirilmesi yönetim ve paydaş katılımı ile gerçekleştirilmektedir. Ancak belediye proje yönetimlerinin, geniş bir kurumsal sınıflandırma sisteminden yoksun oldukları söylenebilir.

Yerel yönetimlerimizde iş kırılım yapıları (IKY), zaman çizelgeleri kullanılarak oluşturulmakta ve genellikle Excel veya MS Project programları üzerinden takip edilmektedir. Proje yöneticisinin takdirine bağlı olarak yerel bir İKY kullanılmaktadır. Teslim edilen veriler genellikle bu İKY ile ilişkilendirilebilir ve özet faaliyetler için tutarlıdır. Bir diğer yandan, İKY tüm faaliyetler için tutarlı olmamaktadır. Ayrıca değişim denetimi için İKY'nı referans göstermek mümkün değildir. Kapsam yönetimi bilgi alanında yerel yönetimlerimiz, en düşük notu bu alt başlıkta almışlardır.

Yapılan çalı̧̧ma ile birlikte, kapsam değişiklik denetiminin daha çok, şartnameye uygunluk boyutu ile değerlendirildiği sonucuna varılmıştır. Kapsama dair değişiklikler 
tüm boyutları ile ele alınmakta, buna ek olarak paydaş talepleri de göz önünde bulundurularak değişiklikler yapılabilmektedir. Genellikle, projelerde bir değişim denetim süreci uygulanmaktadır. Performans ölçme teknikleri de kısmen uygulanmaya çalışılmaktadır. Ancak, değişim denetimi bilgi alanı ile bütünleştirilmemiştir.

Tüm bu veriler göz önünde bulundurulduğunda, yerel yönetimlerimizin PY olgunluk seviyesinin kapsam yönetimi bilgi alanında genel olarak üçüncü seviyede olduğu saptanmıştır.

\subsection{Proje Zaman Yönetimi}

Yerel yönetimlerimizde PY olgunluk seviyelerini belirlemek adına incelediğimiz ikinci PY bilgi alanı, proje zaman yönetimidir. Proje zaman yönetiminde yerel yönetimlerimizin özet durumu aşağıda sunulmuştur (Şekil 4).

Şekil 4. Proje Zaman Yönetimi Olgunluk Değerlendirmesi

\begin{tabular}{|c|c|c|c|c|c|}
\hline \multirow{10}{*}{ 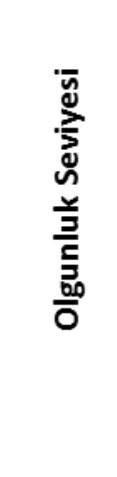 } & \multirow{4}{*}{$\begin{array}{l}5,00 \\
4,50 \\
4,00 \\
3,50 \\
3,00\end{array}$} & & & & \\
\hline & & & & & \\
\hline & & & & & \\
\hline & & & & & \\
\hline & 2,50 & & & & \\
\hline & 2,00 & & & & \\
\hline & 1,50 & & & & 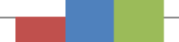 \\
\hline & 1,00 & & & & \\
\hline & 0.00 & & & & \\
\hline & & $\begin{array}{c}\text { Zaman } \\
\text { Yönetimi Bilgi } \\
\text { Alanı }\end{array}$ & $\begin{array}{c}\text { Zaman } \\
\text { Çizelgesinin } \\
\text { Geliştirilmesi }\end{array}$ & $\begin{array}{c}\text { Zamanlama } \\
\text { Denetimi }\end{array}$ & $\begin{array}{l}\text { Zamanlama } \\
\text { Entegrasyonu }\end{array}$ \\
\hline — En düşü & viye & & 2,00 & 1,00 & 1,50 \\
\hline Ortalam & eviye & 2,05 & 2,25 & 1,50 & 2,42 \\
\hline En Yüks & eviyesi & & 3,00 & 2,50 & 3,00 \\
\hline
\end{tabular}

İncelenen yerel yönetimlerimizde, zaman çizelgeleri genellikle, Excel veya MS Project uygulamaları kullanılarak hazırlanmaktadır. Ancak zaman planlarının tüm gerekli detayları içerdiği söylenemez. Dolayısıyla, İKY'nın ayrıntılı programlama için temel olarak kullanılmadığı görülmüştür. Stratejik proje hedefleriyle uyumlu yönetim kararları düzenli olarak izlenmemektedir. Ayrıca, öğrenilen dersler belgelenmediği için, proje zaman yönetiminde yapılan hataların tekrar etme olasılığı da oldukça yüksektir.

Zamanlama denetiminde ise, zaman çizelgeleri denetiminin düzenli olarak gerçekleştirildiği ve proje yöneticilerinin gerekli durumlarda programda revizyon için 
BILIR, INCE | Enterprise Project Management Maturity Model and Applications...

inisiyatif kullanabildiği sonucuna varılmıştır. Fakat önemli görevler için performans karşılaştırmaları oluşturulmamaktadır. Kazanılan değerler gibi ek veriler de oluşturulamadığı için hataların tekrarına sebebiyet verilebilmektedir.

Zamanlama entegrasyonuna dair elde edilen veriler ise, zaman çizelgelerinin tüm proje ekibi, tedarikçiler ve müşteriler tarafından gözden geçilip onaylandığını ortaya koymaktadır. Ancak, zaman yönetimi süreçleri için kullanılan iyileştirme prosedürlerinin varlı̆̆ından söz etmek mümkün değildir.

Bütün veriler göz önünde bulundurulduğunda, yerel yönetimlerimizin zaman yönetimi bilgi alanında, PY olgunluk modelinin ikinci seviyesinde olduğu söylenebilir. $\mathrm{Bu}$ seviyede temel süreçlerin varlığından bahsedilebilir, fakat planlama ve çizelgeleme için yeterli değildir. Diğer yandan da büyük ve görünür projeler için kullanılan tek biçim programlama yaklaşımları olmakla birlikte, bu yaklaşımlar tüm projelerde kullanılmamaktadır. Yerel yönetimlerimizin proje zaman yönetimi alanındaki önemli eksikliklerinden bir tanesi de proje planlarının denetim amacı ile sabitlendiği "temel alma" uygulamasının pek kullanılmıyor olmasıdır.

\subsection{Proje Maliyet Yönetimi}

Çalışma çerçevesinde olgunluk seviyesi belirlenen bir diğer PY bilgi alanı ise proje maliyet yönetimidir. Proje maliyet yönetimi bilgi alanı kapsamında, proje bütçesi belirlenerek projenin onaylanan bütçe dahilinde tamamlanmasının sağlanması beklenmektedir. Proje maliyet yönetimi bilgi alanında elde edilen sonuçlar şekil 5'de sunulmuştur.

\section{Şekil 5. Proje Maliyet Yönetimi Olgunluk Değerlendirmesi}

\begin{tabular}{|c|c|c|c|c|c|c|}
\hline \multirow{2}{*}{\multicolumn{2}{|c|}{$\begin{array}{l}5,00 \\
4,50\end{array}$}} & & & & & \\
\hline & & & & & & \\
\hline \multirow{8}{*}{ 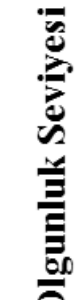 } & 4,00 & & & & & \\
\hline & 3,50 & & & & & \\
\hline & 3,00 & & & & & \\
\hline & 2,50 & & & & & \\
\hline & 2,00 & & & & & \\
\hline & 1,50 & & & & 1 & \\
\hline & 1,00 & & & & & \\
\hline & 0,50 & & & & & \\
\hline & 0,00 & $\begin{array}{l}\text { Maliyet } \\
\text { Yönetimi } \\
\text { Bilgi Alanı }\end{array}$ & $\begin{array}{c}\text { Proje } \\
\text { Maliyet } \\
\text { Tanımlaması }\end{array}$ & $\begin{array}{c}\text { Kaynak } \\
\text { Planlaması }\end{array}$ & $\begin{array}{l}\text { Performans } \\
\text { Ölçümü }\end{array}$ & $\begin{array}{l}\text { Maliyet } \\
\text { Denetimi }\end{array}$ \\
\hline En di & Seviye & & 2,50 & 1,00 & 2,00 & 1,50 \\
\hline Orta & Seviyesi & 2,13 & 2,92 & 1,08 & 2,25 & 2,25 \\
\hline En Yi & Seviyesi & & 3,00 & 1,50 & 3,00 & 3,00 \\
\hline
\end{tabular}

Hacettepe University Journal of Economics and Administrative Sciences $\mid$ 
Proje maliyet tanımlaması adına elde ettiğimiz sonuçlar, yerel yönetimlerimizde proje bütçesi oluşturulması sırasında birim fiyatlar kullanılarak maliyetlerin detaylı bir şekilde tanımlandığını göstermektedir. Fakat risk planlaması ve geçmiş projelere dair bütçeleme verileri genellikle göz ardı edilmektedir.

Kaynak planlaması verilerine bakıldığında ise detaylı bir finansal kaynak planlaması yapıldığı, fakat rol ve yetenek planlarının oldukça yüzeysel bir şekilde gerçekleştirildiği söylenebilir. Tüm bunların yanında performans ölçümü açısından bakıldığında planlanan ve gerçekleşen bütçe karşılaştırmalarının daha çok proje sonunda gerçekleştirildiği görülmektedir.

Bütçe karşılaştırma verilerinin sonraki projelerde kullanılıp kullanılmayacağına dair bir takip sisteminin olmaması da yerel yönetimlerin maliyet yöntemi bilgi alanındaki önemli eksikliklerinden bir tanesidir. Maliyet denetiminde ise mali verilerin izlenmesi ve gerekli değişikliklerin yapılması için önceden belirlenmiş olan mevzuat kullanılmaktadır.

Tüm bu veriler değerlendirildiğinde, yerel yönetimlerin, proje maliyet yönetimi olgunluk seviyesinin ikinci basamağında olduğunu söyleyebiliriz. $\mathrm{Bu}$ olgunluk seviyesinde, projeye dair maliyet tahminleri, raporlama ve performans ölçümleri gerçekleştirilmekte, bunun yanında, büyük ve görünür projeler için maliyet yönetimi süreçleri daha etkin bir şekilde kullanılmaktadır. Fakat öğrenilen dersler belgelenmemektedir.

\subsection{Proje Kalite Yönetimi}

Proje kalite yönetimi, projede istenilen tüm gereksinimlerin erken aşamalarda katılımcı bir şekilde belirlenmesini ve proje sonucunda ortaya çıkacak çıktının da bu gereksinimleri karşılamasını sağlamayı hedeflemektedir. Bu alanda elde edilen sonuçlar da aşağıda Şekil 6'da özet halinde sunulmuştur.

Yerel yönetimlerimizde, kalite planlaması ve kalite denetimleri mevzuat ile belirlenen çerçevede gerçekleştirilmektedir. Ayrıca proje boyunca bazı ölçütler takip edilmektedir. Kalite güvencesinin sağlanması boyutunda ise proje ekibinin öncelikli olarak mevzuat gereksinimlerini daha sonra ise kendi gereksinimlerini göz önünde bulundurarak çalışmalar gerçekleştirdiği söylenebilir. 


\section{Şekil 6. Proje Kalite Yönetimi Olgunluk Değerlendirmesi}

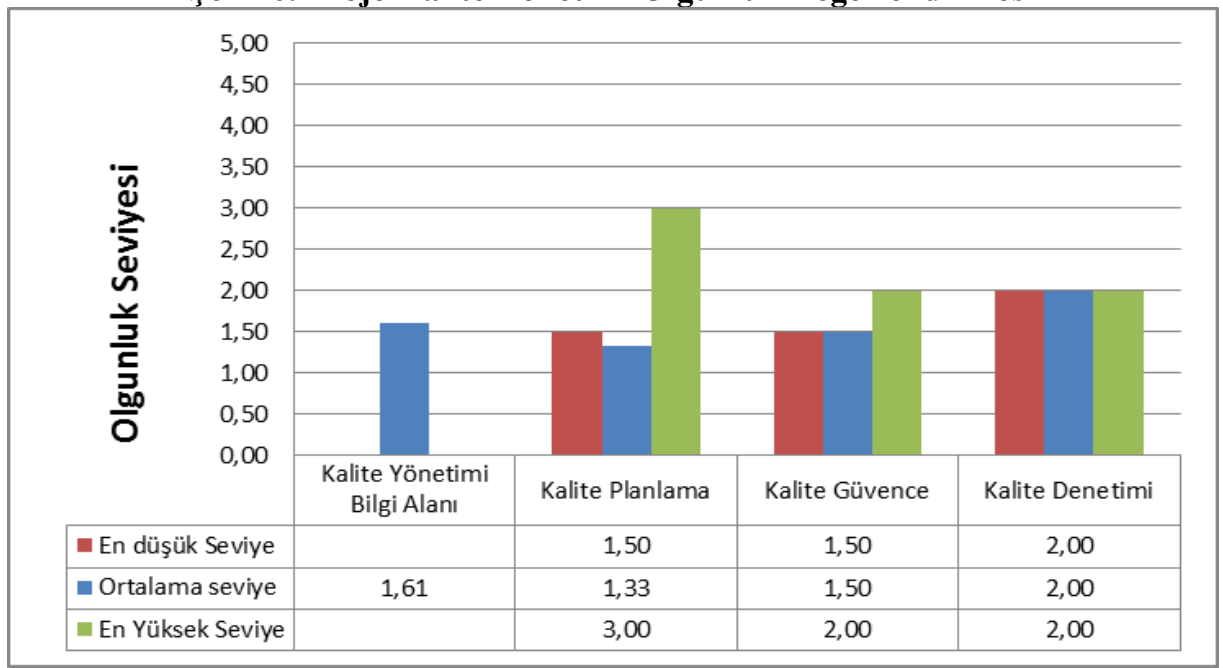

Kalite denetimi açısından, iç denetim yapısı sağlanarak proje çıktıları şartnameyle bütünleştirilmeye çalışılmaktadır. Sonuç olarak elde edilen tüm veriler 1şı̆̆ında yerel yönetimlerin, proje kalite yönetimi olgunluk seviyesinin ikinci aşamasında olduğu söylenebilir. $\mathrm{Bu}$ aşamada, temel organizasyonel proje kalite politikası belirlenmiştir. Bunun yanında, kalite politikası genellikle büyük ve görünür projeler üzerinde uygulanmaktadır. Ancak geri beslenmeler için yönergeler oluşturulmamıştır.

\subsection{Proje Risk Yönetimi}

Proje risk yönetimi bilgi alanının da PY olgunluk seviyesinin belirlemesinde yadsınamayacak bir önemi vardır. Eğer bir projenin başlangıcından bitişine kadar risk faktörleri tanımlanıp, analiz edilir ve ardından denetimi sağlanırsa projede oluşması muhtemel tüm sapmaların önüne geçilme ihtimali artacaktır. Bu bilgi alanındaki sonuçlar da Şekil 7'de sunulmuştur. 


\section{Şekil 7. Proje Risk Yönetimi Olgunluk Değerlendirmesi}

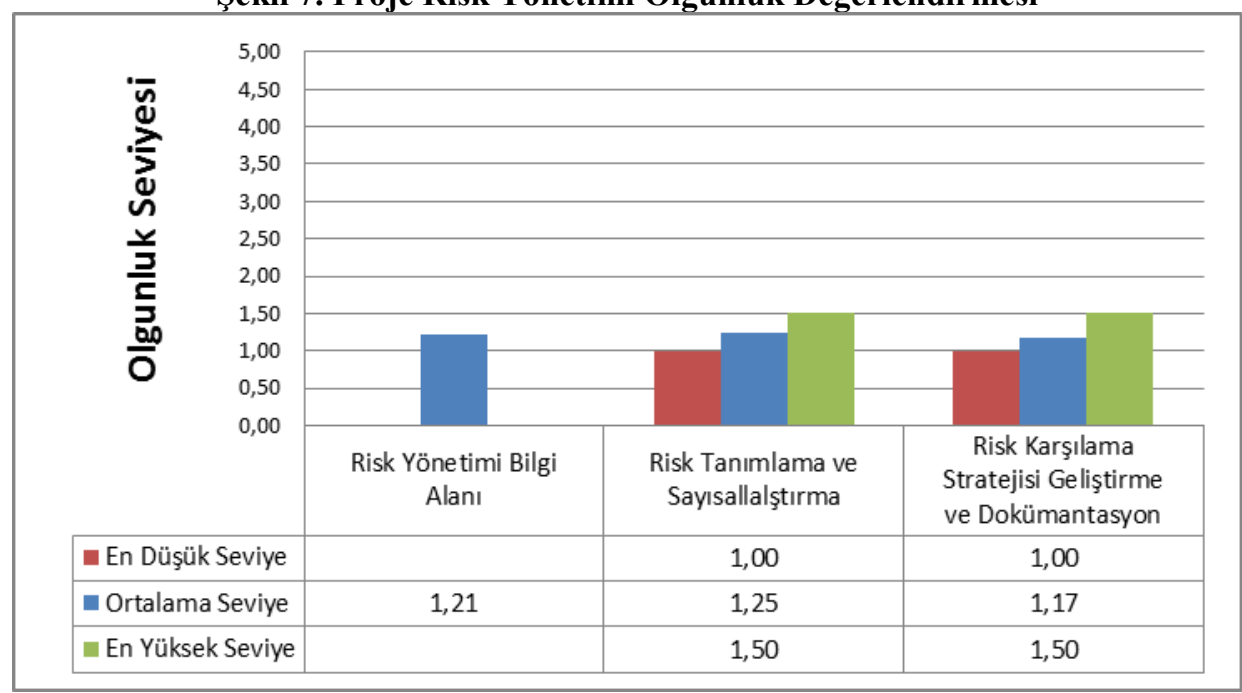

Yerel yönetimlerin proje risk yönetimi yaklaşımları değerlendirildiğinde, bu konuda bir ölçütün oluşturulmadığı ve gerçek bir uygulamanın söz konusu olmadığı kanaatine varılmıştır. Büyük projelerde oluşması muhtemel bazı riskler ele alınsa da risk yanıtları yalnızca krize dayalı olacak şekilde reaktif ve belirsizdir. Risk karşılamaya yönelik stratejiler geliştirilmemekte ve sadece istisnai durumlarda risk belgelendirmesi yapılmaktadır.

Tüm bu faktörler değerlendirildiğinde risk yönetimi bağlamında yerel yönetimlerin henüz birinci olgunluk seviyesinde olduğunu söylemek mümkündür. Sonuç olarak, yerleşik uygulama ve ölçütler bulunmamaktadır. Belgelendirme yoktur veya çok kısıtlıdır. Yönetimin, risk yönetiminde aktif olarak yer almaması projeler için ciddi bir tehdittir.

\subsection{Proje İnsan Kaynakları Yönetimi}

İncelenen PY bilgi alanlarından bir diğeri de insan kaynakları yönetimi bilgi alanıdır. Etkili bir insan kaynakları yönetimi yapılabilmesi için belirli proje faaliyetlerinde gereksinim duyulan kaynak ve beceriler tanımlanmalıdır. Bunun yanında, proje için gerekli roller ve sorumluluklar da belirlenmelidir.

Proje insan kaynakları yönetiminin alt başlıklarından organizasyonel planlama açısından yerel yönetimlerimizin değerlendirmesi neticesinde şu sonuçlara ulaşılmıştır: Personel atamaları mevcut insan kaynaklarına uyacak şekilde gerçekleştirilmektedir. Bununla birlikte proje yöneticisi ve ekibinin beceri gereksinimlerinin tanımlandığı ve sorumluluklarının tam olarak belirlendiği söylenilemez. Organizasyonel planlama süreci 
tamamen projenin sahibi yerel iş biriminde uygulanmakta diğer paydaşlara yaygınlaştırılmamaktadır. Tüm yerel yönetimler genelinde, insan kaynaklarının organizasyon çapında planlanması, kaynak dengeleme ve önceliklendirme gerçekleştirilememektedir.

Şekil 8. Proje İnsan Kaynakları Yönetimi Olgunluk Değerlendirmesi

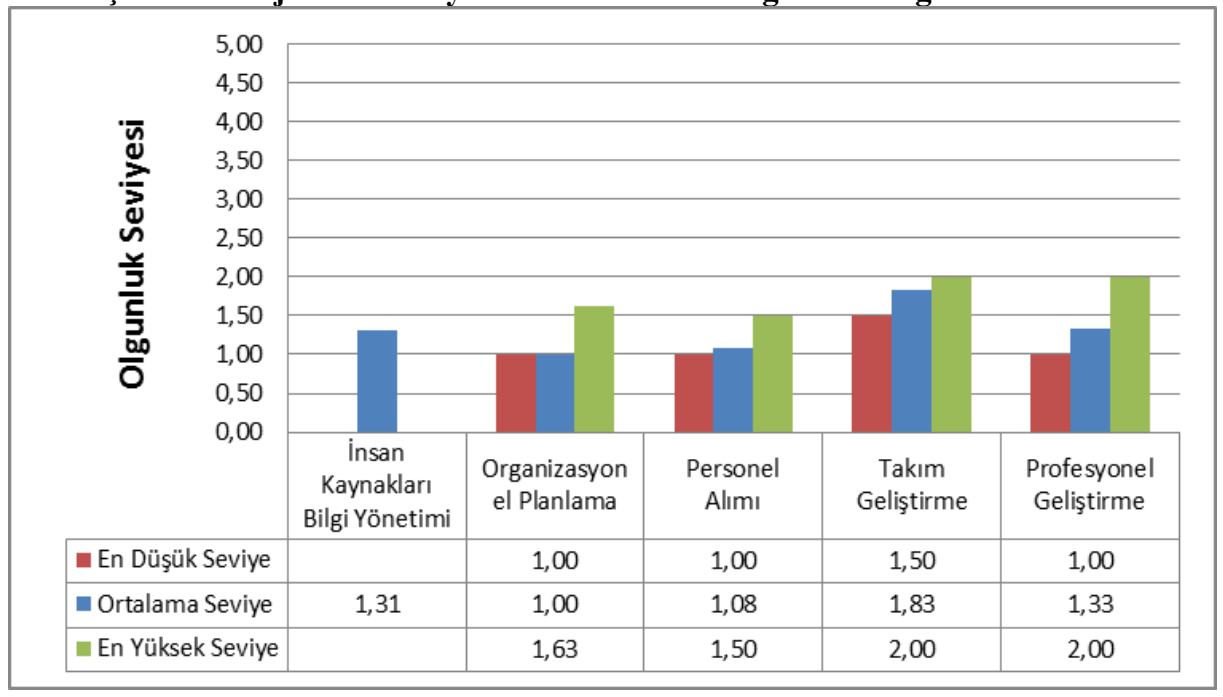

Proje personel alımları genellikle anlık gereksinimler doğrultusunda gerçekleştirilmekte, uzun dönemli proje kaynak planlamaları yapılmamaktadır. Aynı zamanda personele ait beceri veritabanının kullanılmadı̆̆ını da söyleyebiliriz. Dolayısıyla, mevcut kaynak havuzunda bulunan personelin kişisel beceri ve deneyimleri projeye uygun şekilde kullanılamamaktadır.

Bir diğer yandan bazı yerel yönetimlerimizin, kurum personeline PY eğitimleri aldırdığını ve proaktif toplantılar düzenleyerek birlikte çalışma faaliyetlerini desteklediğini söyleyebiliriz. Fakat proje ekipleri zaman zaman kendi içlerinde eşgüdüm sorunu da yaşamaktadır.

Proje insan kaynakları yönetimi profesyonel geliştirme alt grubu yönünden de yerel yönetimlerimiz, oldukça zayıftır. Proje yöneticileri yalnız başarı olasılığına dayalı olarak atanmaktadır. Buna ek olarak, PY kariyer yolu kapalıdır. Genellikle, proje ile ilgili olan kariyer ve eğitim gereksinimleri de tanımlanmamıştır.

\subsection{Proje İletişim Yönetimi}

Proje iletişim yönetimi kapsamında, projeye ait bilgilerin sınıflandırılarak oluşturulması, belirlenen yöntem ve araçlarla yaygınlaştırılması ve karar vermeye 
yardımcı olacak şekilde yönetilmesi gerekmektedir. İletişim yönetimi kapsamında elde edilen sonuçlar aşağıda şekil 9'da sunulmuştur.

Şekil 9. Proje İletişim Yönetimi Olgunluk Değerlendirmesi

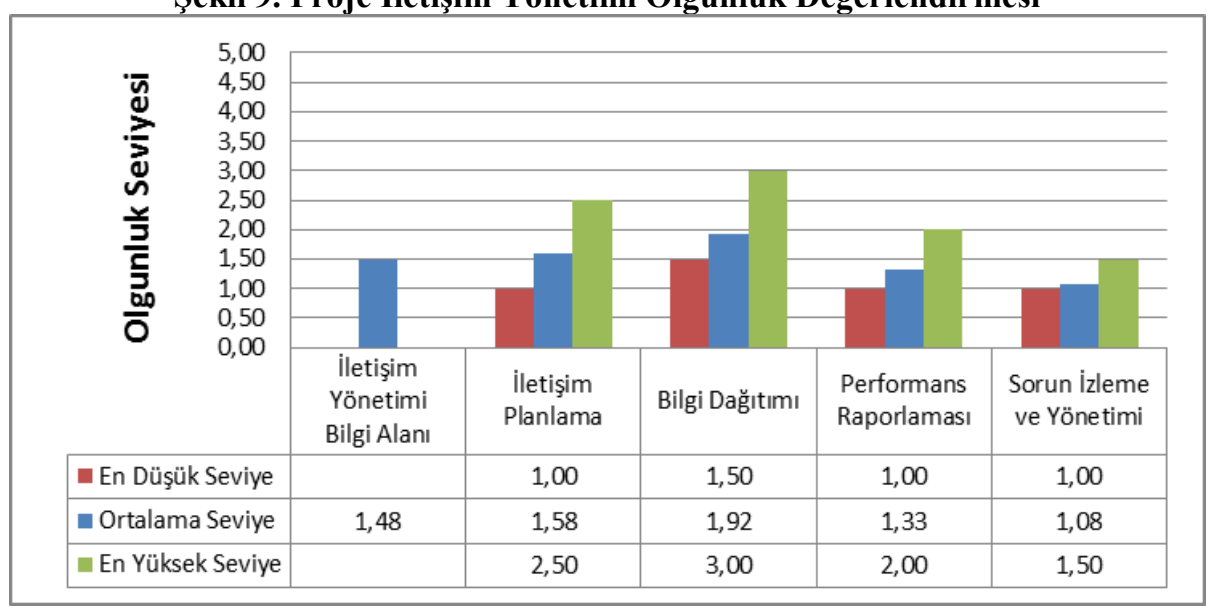

Proje iletişim planlama başlığı altında, yerel yönetimlerimizde kurumsal iletişim ölçütlerinin belirlendiğini ve ortak bir formatın geliştirildiğini söyleyebiliriz. Bunun yanı sıra, proje yöneticisi projenin durumunu periyodik olarak raporlamayı hedef edinmektedir. Fakat iletişim planı proje boyunca güncellenmediği ve süreç iyileştirmelerden yoksun olduğu için hataların tekrarı muhtemeldir.

İletişim yönetimi bilgi dağıtımı alt grubunda ise, proje müddetince gerekli bilginin proje gereksinimlerine göre dağıtıldığı söylenebilir. Genel bir iletişim altyapısı oluşturmak adına çalışmalar yürütüldüğü de görülmektedir. Ayrıca, genellikle basılı veya elektronik dosyalar ekip üyeleri ve paydaşlar ile düzenli olarak paylaşılmaktadır. Fakat bir veritabanı üzerinden bilgi edinme durumundan bahsetmek söz konusu değildir.

Performans raporlaması ise proje yöneticilerinin belirlenen zaman aralıkları ve genel yapıya uygun olarak raporlamasıyla gerçekleştirilmektedir. Ancak bu aşamada süreç gayri resmi olarak yani yalnızca proje yöneticisi ile görüşülerek ilerlemektedir. Bunun yanında, projeye dair öğrenilen dersler derlenmemiş ve tüm kuruluşla paylaşılmamıştır.

Projelerde karşılaşılan sorunlar genellikle toplantılarda ele alınarak çözüme kavuşturulmaya çalışılmaktadır. Bu sorunlar ancak gerektiğinde oluşturulan geçici listelerle kayıt altına alınmaktadır. Ayrıca sorun yönetim süreci, kapsam değiştirme denetimi süreci ile bütünleştirilmemiştir. 
Bütün veriler 1şı̆̆ında yerel yönetimlerin iletişim yönetimi olgunluk seviyesinin genel olarak ikinci aşamasında olduğu söylenebilir. Bu aşamada temel iletişim süreçleri belirlenmiştir ancak genellikle büyük ve görünür projelerde takip edilmektedirler.

\subsection{Proje Tedarik Yönetimi}

Yerel yönetimlerin PY olgunluk seviyesinin belirlenmesi amaciyla incelememiz gereken son bilgi alanı, proje tedarik yönetimidir. Bu bilgi alanında elde edilen sonuçlar aşağıda Şekil 10 'da sunulmuştur.

\section{Şekil 10. Proje Tedarik Yönetimi Olgunluk Değerlendirmesi}

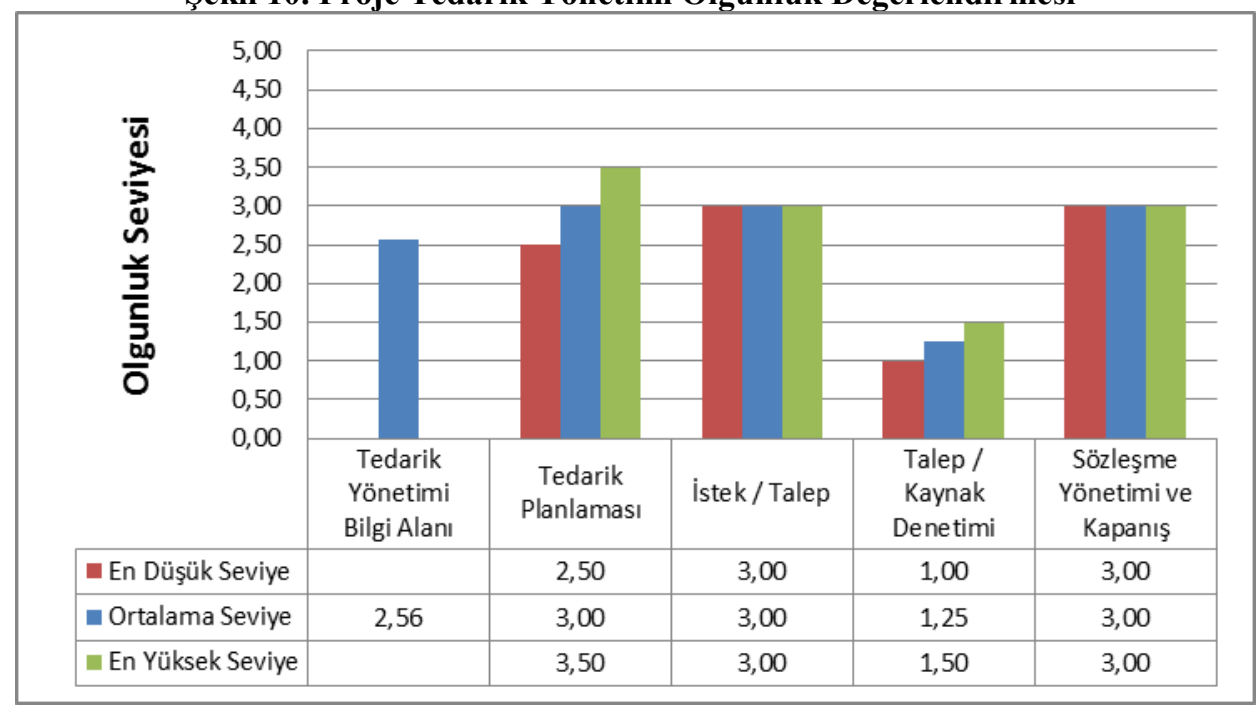

Yerel yönetimlerimiz, tedarik yönetimini genellikle ihale kanunu çerçevesinde, mevzuat kapsamında belirlendiği gibi yürütmektedir. Tüm yerel yönetimlerimizde satın alma birimi vardır ve onaylanmış tedarikçiler ile çalışılmaktadır. Fakat tedarikçilerin performansı değerlendirilmemektedir. Tedarik planlaması çerçevesinde, oluşturulan şartnameler ve teknik raporlar ile tedarik edilecek ürün ve hizmetler belirlenmektedir.

İstek / talep alt grubunda, tercih edilen satıcılar şartnamelerde istenilen iş bitirme ve iş deneyimi gibi belgeler ile kısıtlanmaktadır. Proje durumuna göre sözleşmeler temel alınarak istekler belirlenmektedir. Genellikle sürekli iyileştirme yapılmamakta, bunun yanı sıra, tercih edilen satıcı listeleri tutulmamaktadır.

Talep ve kaynak denetimi alt grubunda ise, satın almalara dair denetimlerin basit prosedürlerle oluşturulan muayene kabul komisyonu tarafından yapıldığı söylenebilir. Genellikle, tedarikçiler PY süreçleri ve İKY kullanarak detaylı planlar oluşturmamaktadır. Bu da denetimlerin etkinliğini oldukça azaltmaktadır. 
Sözleşme yönetimi ve kapanışı alt grubunda ise geçici ve kesin kabullerin süreçlere uygun gerçekleştiği sonucu elde edilmiştir. Bunun yanında, düzenli raporlama dosyaları bulunmamaktadır. Yine paydaşlarla stratejik ortaklıkların kurulduğundan bahsetmek mümkün değildir.

Tüm bu bilgiler doğrultusunda, yerel yönetimlerin tedarik yönetimi bilgi alanındaki olgunluk seviyesinin genel olarak üçüncü aşama olduğu görülmektedir. Tedarik sürecinin düzenli olarak gözden geçirilmemesi, süreç iyileştirmenin gerçekleştirilememesi ve verimliliğin düşmesi sonuçlarını doğuracağı için önemli bir handikaptır.

\section{SONUC}

Yapılan bu çalışma ile yerel yönetimlerimizin özellikle bazı PY bilgi alanlarında olgunluk seviyelerinin düşük olduğu sonucuna ulaşılmıştır. Bu sonuç da bize, yerel yönetimlerimizde PY alanında çok önemli gelişme alanlarının bulunduğunu ve bunun da toplumsal refah ve ülke gelişimini desteklemek adına önemli firsatlar sunduğunu göstermektedir.

Proje yönetiminin kapsam yönetimi ve tedarik yönetimi bilgi alanlarında, yerel yönetimlerimizin olgunluk seviyeleri, 4734 sayılı kamu ihale kanununa uygunluk esas alınarak çalışmalar gerçekleştirildiği için diğer bilgi alanlarına göre net bir şekilde daha yüksektir.

Proje kapsam yönetimi genel olarak değerlendirildiğinde, yerel yönetimlerimizin olgunluk modelinin üçüncü aşamasında (tanımlanmış aşama) olduğunu söyleyebiliriz. $\mathrm{Bu}$ aşamada tüm kritik süreçler tanımlanmış ve bir yönetim kültürü haline getirilmiştir. Bu durumda kamu ihale kanunun bir zorunluluk olarak uygulanması ve bu kanunun da gereksinimlerin net bir şekilde tanımlanarak geliştirme sürecinin de buna uygun olarak yürütülmesini zorunlu tutması önemli bir etkendir. Yine de yerel yönetimlerimizin bu bilgi alanında kendilerini geliştirebilecekleri imkanlar da mevcuttur. Gereksinim belirleme sürecinin tüm paydaşlar göz önünde bulundurularak hazırlanması, öğrenilen derslerin belgelendirilmesi ve kapsam değişiklik sürecinin gerekli hallerde katılımcı bir şekilde işletilebilmesi bu alanda geliştirmesi gereken konulardır.

İncelenen yerel yönetimlerimizde proje tedarik yönetimi büyük oranda kamu ihale kanunu çerçevesinde gerçekleştirilmektedir. Tüm yerel yönetimlerimizde satın alma birimi vardır ve onaylanmış tedarikçiler ile çalışılmaktadır. Bununla birlikte tedarikçilerin performansı özel olarak değerlendirilmemekte ve süreç gözden geçirmeleri gerçekleştirilmemektedir. Bu bilgiler doğrultusunda yerel yönetimlerin tedarik yönetiminde üçüncü olgunluk seviyesinde olduğu söylenebilir. Yerel yönetimlerimizin kendilerini geliştirebilmeleri için her proje sonunda tedarikçi 
performans değerlendirmesi gerçekleştirmeleri, ayrıca tedarik sürecini düzenli olarak gözden geçirmeleri gereklidir.

Proje maliyet, zaman, kalite ve iletişim yönetimi bilgi alanlarında ise yerel yönetimlerimizin mevcut uygulamaları ikinci olgunluk seviyesi civarındadır. Bu alanlarda mevzuatın belirlediği tek biçim formlar, kamu birim fiyat kitapçıkları, idari sözleşme taslakları vb. uygulamalar mevcuttur. Bununla birlikte burada sayılanlar dışında gerekli birçok uygulamanın da eksik olduğu görülmüştür.

Proje maliyetinin yönetilebilmesi amacıyla proje bütçeleri oluşturulmakta, raporlama ve performans ölçümleri de gerçekleştirilmektedir. Oluşturulan maliyet kodları, kamu birim fiyat kitapçıkları ve İKY uygun olarak takip edilmektedir. Bunun yanında, büyük ve görünür projeler için maliyet yönetimi süreçleri daha etkin bir şekilde yönetilmektedir. $\mathrm{Bu}$ alandaki önemli bir eksiklik, proje maliyet gerçekleşmelerinin düzenli bir şekilde, maliyet temel çizgisi ile karşılaştırılarak takip edilmemesidir. Proje yönetiminin ileri olgunluk seviyelerinde olduğu gibi öğrenilen dersler belgelendirilmemektedir.

Proje zaman yönetiminde yüksek olgunluk seviyesine sahip bir organizasyonun tüm projeler için zaman programları oluşturması ve projelerini bu zaman programlarını temel alarak yürüterek ilerlemeyi sürekli denetlemesi beklenir. Yerel yönetimlerimizde proje zaman yönetimi temel süreçlerinin varlığından bahsedilebilir, fakat yeterli değildir. Büyük ve daha görünür projeler için kullanılan standart yaklaşımlar vardır ancak bunlar tüm projelerde kullanılmamaktadır. Detaylı ve entegre zaman programı oluşturmanın tüm projeler için bir standart haline getirilmesi kaçınılmazdır. Bu alandaki önemli bir eksiklik, proje planlarından sapmaları denetlemek amacıyla, "temel alma" uygulamasının olmamasıdır. Geçmiş verileri kullanım ve belgelendirme açısından eksik olan yerel yönetimlerin, aynı zaman yönetimi hatalarını tekrar etme ihtimalleri yüksektir.

PY olgunluk seviyesinde değerlendirilen bir diğer bilgi alanı ise proje kalite yönetimidir. Yerel yönetimlerimiz, proje kalite politika ve standartlarını hazırlanan ihale dokümanı eklerindeki teknik şartnameler ile belirlemektedir. Her proje için kalite hedefleri ve standartları ayrıca oluşturulmamaktadır. Dolayısıyla, kalite standartlarının yönetilmesi noktasında esnek davranılmaktadır. Bu da süreç geliştirme çalışmalarını aksatmaktadır. Kalite gereksinimlerine uygunluğu izlemek için raporlamalar yapılmamakta, kalite gereksinimleri açısından iç denetim mekanizması tam olarak işletilememektedir.

Proje iletişim yönetimi bilgi alanı, gerekli verilerin toplanması, sınıflandırılması ve nasıl kullanılacağına projenin henüz planlama aşamasında karar verilmesi ile 
ilgilidir. Yerel yönetimlerimizde temel iletişim süreçleri belirlenmiştir. Fakat bu süreçlerin uygulaması genellikle büyük projelerle sınırlıdır. Dolayısıyla zaman, maliyet ve kapsamı içeren ilerleme raporları yalnızca büyük projelerde oluşturulmaktadır. Proje iletişim yönetimi süreçlerine tüm proje ekipleri aktif olarak katılmadığı için iletişim kopuklukları ve proje hedeflerinden sapmalar gerçekleşebilmektedir.

Proje risk yönetimi ve insan kaynakları yönetimi olgunluk seviyesinin yerel yönetimlerimizde diğer bilgi alanlarına kıyasla daha düşük seviyede, henüz birinci seviyede (başlangıç) olduğu görülmüştür.

Proje risk yönetimi bilgi alanında organizasyonların, proje risk olasılıklarının tanımlayarak analiz etmeleri, belirlenen riskler için risk yanıt stratejileri oluşturmaları ve bu stratejiler ile riskleri proje boyunca sürekli takip etmeleri beklenir. Fakat bu konuda yerel yönetimlerimiz herhangi bir uygulama ve standart belirlememişlerdir. Bunun yanında, risk yönetimi dokümantasyonu da yoktur.

Proje insan kaynakları yönetimi kapsamında proje faaliyetleri için ihtiyaç duyulan rol ve beceriler tanımlanmalı, proje için gerekli sorumluluklar belirlenmelidir. Yerel yönetimlerimizde projeler için personel atamaları genellikle mevcut insan kaynaklarına uyacak şekilde düzenlenmektedir. Proje yöneticisi ve ekibinin beceri gereksinimlerinin tanımlandığı ve sorumluluklarının belirlendiği söylenilemez. Gerekli insan kaynaklarının organizasyonel planlaması, proje kaynak dengelemesi ve önceliklendirme çalışmaları gerçekleştirilmemektedir. Yerel yönetimlerimizin bu alanda olgunluk seviyesini artırması için bu eksiklikleri gidermesi gereklidir.

Çalışmadan elde edilen diğer önemli bir diğer sonuç ise, yerel yönetimlerimiz arasında olgunluk seviyesi açısından önemli farklılıklar olmadığıdır. Bununla birlikte, yine de bazı bilgi alanlarında yerel yönetimlerimiz arasında nispi farklılıklar olduğu tespit edilmiştir. $\mathrm{Bu}$ göreceli farklılığın temel sebebi, bazı yerel yönetimlerimizde stratejik planlama ve yönetim faaliyetlerinin daha etkin bir şekilde yürütülmesi ve önemli projelerin stratejik yönetim ekibi tarafindan yönetilmesidir. Yine bazı yerel yönetimlerimizde daha etkin ve proaktif bir şekilde yürütülen kalite güvence çalışmaları da proje olgunluk seviyesinin bu organizasyonlarda bazı bilgi alanlarında daha yüksek olmasını sağlamıştır.

PY olgunluk seviyelerini karşılaştırdığımızda elde edilen bir diğer sonuç ise, Büyükşehir Belediyesinin, olumlu manada diğer yerel yönetimlerden olumlu manada ayrışmasıdır. $\mathrm{Bu}$ ayrışmanın en önemli sebeplerinden bir tanesi büyükşehir belediyesinde daha kurumsal firmalar ile birlikte daha çok paydaşı içeren kritik öneme sahip projeler yürütülüyor olmasıdır. Bu projeleri yönetebilmek ve izleyebilmek için belirlenmiş ve uygulanan PY süreçlerinin varlı̆̆ıdır. $\mathrm{Bu}$ süreçlerle birlikte proje ilerlemeleri zaman, bütçe ve kalite gibi farklı boyutlarla düzenli bir şekilde takip 
edilerek raporlanmaktadır. Yine büyükşehir belediyesindeki önemli farklılıklardan bir tanesi de stratejik yönetim ile birlikte çalışan bir PY ofisinin var olması ve bu ofisin sertifikalı proje yöneticileri barındırıyor olmasıdır. Büyükşehir belediyesinde, proje yönetiminde PMI metodolojisinin kısmen de olsa takip ediliyor olması birçok alanda olgunluk seviyesinin daha üst düzeyde olmasını sağlamıştır. Daha etkin bir şekilde yürütülen kalite güvence faaliyetlerinin de PY olgunluk seviyesinin daha yüksek olmasında kısmi bir etkisi vardır.

$\mathrm{Bu}$ çalışma sonuçlardan çıkarılabilecek belki de en önemli öneri, "kamu ihale kanunu”nun, PY gerekliliklerini de göz önünde bulundurarak geliştirilmesi olacaktır. Bu geliştirmenin nasıl olacağı ayrı bir çalışma konusu olmakla birlikte, proje gerekliliklerinin toplanması, düzenli raporlamanın ve katılımcıllı̆ın sağlanması, iletişimin planlanarak yönetilmesi vb. konuları da mutlaka içermesi gereklidir.

Bunun yanında yerel yönetimlerimizdeki iç denetim mekanizmasının sonuçların denetlenmesinden ziyade proaktif bir yaklaşımla geliştirilerek kalite güvence faaliyetlerinin artırılması, stratejik planlama organizasyonları ile birlikte çalışan birkaç kişilik de olsa proje ofisleri oluşturulması, ofislerin profesyonel proje yöneticileri içermesi, ofis çalışanlarının eğitim ve metodoloji çalışmaları ile güçlendirilmesi bu alanda atılabilecek önemli adımlardır.

$\mathrm{Bu}$ çalışma İstanbul ilinde yer alan sınırlı sayıda yerel yönetimlerimizin PY faaliyetleri temel alınarak, sınırlı bir zaman dilimi içerisinde gerçekleştirilmiştir. Bu çalışmanın bir benzeri farklı bir bölgemizde yer alan yerel yönetimlerimize uygulanarak sonuçların karşılaştırılması sağlanabilir. Yine farklı olgunluk modelleri uygulanarak sonuçların karşılaştırılması da mevcut çalışmanın geliştirilmesi için kullanılabilir. Çalı̧̧mada elde edilen en önemli sonuçlardan bir tanesi de PY teknik ve süreçlerinin Kamu İhale Kanunu'na ilave edilerek PY olgunluk seviyesinin artırlabileceği gerçeğidir. Bunun nasıl olması gerektiği ile ilgili detaylı bir çalışma da gerçekleştirilebilir.

\section{KAYNAKÇA}

Backlund, F., D. Chroneer, E. Sundqvist (2014), "Project Management Maturity Models - A Critical Review: A case study within Swedish Engineering and Construction Organizations", Procedia - Social and Behavioral Sciences, 119, 837-846.

Cleland, D.L., L.R. Ireland (2002), Project Management: Strategic Design and Implementation. New York: McGraw Hill Higher Education; 4. bask1 (21 Ağustos 2002).

Cooke-Davies, T. (2004), "Project Management Maturity Models", P. Morris, P. Pinto içinde, The Wiley Guide to Managing Projects. Hoboken, New Jersey: Wiley\&Sons. 
Kurumsal Proje Yönetimi Olgunluk Modeli ve İstanbul Yerel Yönetimler...| BİLİR, İNCE

Cooke-Davies, T.J., A. Arzymanow (2003), "The Maturity of Project Management in Different Industries: An Investigation Into Variations Between Project Management Models", International Journal of Project Management, 21, 471-478.

Crawford, J.K. (2007), Project Management Maturity Model, 2nd Ed. New York: Auerbach Publications.

Demir, C., İ. Kocabaş (2010), "Project Management Maturity Model (PMMM) in Educational Organizations", Procedia-Social and Behovioral Sciences, 9, 1641-1645.

Efe, A. (2018), "Kamu Sektöründe Süreç Olgunluk Düzeyi Ölçümü: Kalkınma Ajansaları Üzerinden Analiz ve Modelleme", Erzincan Üniversitesi Sosyal Bilimler Enstitüsü Dergisi, XI-I, 321-335.

Gorog, M. (2016), “A Broader Approach to Organizational Project Management Maturity Assessment”, International Journal of Project Management, 34, 1658-1669.

Holmes, S.J., R.T. Walsh (2005), Conducting Effective Project Management Maturity Assessment Interviews. Integrated Management Systems, Inc., Ann Arbor, MI.

Kerzner, H. R. (2005), Using the Project Management Maturity Model: Strategic Planning for Project Management. New Jersey, USA: John Wiley\&Sons.

Koçel, P.D. (2007), İşletme Yönetmeliği, Ankara: Arıkan Yayınları.

Kwak, Y.H., H. Sadatsafavi, J., Walewski, N.L. Williams (2015), "Evolution of Project Based Organization: A Case Study”, International Journal of Project Management, 33, 16521664.

Lahrmann, G., T. Metlerr, R. Winter, F. Wortmann, F. Marx (2011), Inductive Design of Maturity Models: Applying the Rasch Algorithm for Design Science Research. Service Oriented Perspectives in Design Science Research, Berlin: Springer Berlin Heidel.

McCormack, K., J. Williems, J.V. Bergh, D. Deschoolmesster, M.I. Stemberger, R. Skrinjar, N. Vlahovic (2009), “A Global Investigations of Key Turning Points in Business Process Maturity”, Business Process Management Journal, 15(5), 792-815.

Nikkhou, S., K. Taghizadeh, S Hajiyakhchali (2016), Designing Portfolio Management Maturity Model (ELENA), Procedia - Social and Behavioral Sciences, 226, 318-325.

OGC. (2015), Office of Government Commerce, Best Management Practice Portfolio.: http://www.gov.uk/government/publications/best-management-practice-portfolio adresinden alınd

Onur, İ. (2007), Proje Yönetiminde Stratejik Planlama ve Olgunluk Modeli Kapsamında Yapılan Bır Uygulama. Dumlupınar Üniversitesi - Sosyal Bilimler Enstitüsü,yüksek lisans tezi.

PMI, (2013a), A Guide to the Project Management Body of Knowledge (PMBOK guide). Newton Square, PA: Project Management Institute, Inc.

PMI, (2013b), Organizational Project Management Maturity Model: OPM3 Knowledge Foundation. Newtown Square, Pennsylvania: Project Management Institute.

Pricewaterhouse\&Coopers, (2012), Insights and Trends: Current Programme and Project Management Practices. PWC.

Schwalbe, K. (2002), Information Technology Project Management, Canada: Course Technology Thomson Learning. 
BILIR, INCE | Enterprise Project Management Maturity Model and Applications...

Steyn, H. (2002), "Project Management Applications of the Theory of Constraints Beyond Critical Chain Scheduling”, International Journal of Project Management, (20), 19-45.

Ünle, A.M. (2007), Yerel Yönetimlerde Projelerin Seçimi ve Çoklu Projelerin Yönetimi. Eskişehir Osmangazi Üniversitesi - Fen Bilimleri Enstitüsü, Yüksek Lisans Tezi.

Yıldız, D.A. (2015), Proje Yönetiminde Olgunluk Seviyesi Ölçülmesine Yönelik Araştırma. Beykent Üniversitesi - Sosyal Bilimler Enstitüsü, Yüksek Lisans Tezi.

Hacettepe University Journal of Economics and Administrative Sciences $\mid$

Vol 37, Issue 3, 2019

422 